\title{
Probing Soot Formation, Chemical and Physical Evolution, and Oxidation: A Review of In Situ Diagnostic Techniques and Needs
}

\author{
H.A. Michelsen \\ Combustion Research Facility, Sandia National Laboratories, Livermore, CA 94550, USA
}

\begin{abstract}
:
Soot is responsible for notoriously detrimental effects on human health, air quality, and global and regional climate. Controlling soot emissions to the atmosphere will require overcoming large gaps in the understanding of soot formation and physical and chemical evolution during combustion. These gaps in understanding are largely attributable to the complexity of the chemical and physical system combined with a paucity of diagnostic techniques available for probing soot non-invasively and under a wide range of combustion conditions. This review briefly summarizes the chemistry of soot formation and evolution during combustion and describes diagnostic tools that are available to make these measurements. Despite the availability and value of a host of ex situ particle diagnostic techniques, because of space limitations, this review is restricted to a discussion of in situ diagnostic methods. The review concludes with a brief discussion of needs for new diagnostic tools to probe soot chemistry.
\end{abstract}

Keywords: Soot; Diagnostics; Formation; Oxidation; Properties 


\section{Introduction}

Soot is formed during the incomplete combustion of hydrocarbon fuels. Because soot radiates strongly at high temperatures, its formation is often desirable under conditions, e.g., in furnaces and boilers, in which high radiative-heat transfer is necessary [1,2]. Conversely, its formation is undesirable when high radiative-heat transfer is a problem, such as in the control and extinction of medium- to largescale pool, urban, and forest fires $[3,4]$ and in efforts to increase efficiency and reduce heat loss in engines [5]. Soot formation also poses threats to human health [6-9], air quality [10], and global and regional climate [10-12] when released into the atmosphere. Fine combustion particulates, particularly soot particles, are cytotoxic and can have substantial adverse effects on cardiovascular and pulmonary health [6-9]. Soot contributes to air pollution predominantly via reactions with nitrogen dioxide $\left(\mathrm{NO}_{2}\right)$ [13-17], sulfur dioxide $\left(\mathrm{SO}_{2}\right)[14,16,18]$, and ozone $\left(\mathrm{O}_{3}\right)$ [16, 19-21]. In addition, soot absorbs radiation strongly over ultraviolet (UV), visible, and infrared (IR) spectral regions and contributes significantly to global warming via direct radiative forcing $[11,12]$ and by secondary effects, such as influencing cloud processes and reducing surface albedo by settling on snow and ice surfaces [11, 12].

There are significant deficiencies in our understanding of particle formation and evolution during combustion [22]. These deficiencies are attributable to a combination of factors, including (1) a lack of sensitive, accurate, noninvasive measurements of the physical and chemical characteristics of soot during its development and evolution in combustors and (2) computational limitations in simulating molecular-weight growth of large gas-phase species, the nucleation of these species to form particles, and the detailed chemistry involved in particle growth, chemical and physical evolution, and oxidation under combustion conditions. Real progress in surmounting these deficiencies in our understanding of soot formation and evolution necessitates overcoming both experimental and computational limitations.

There is a strong need for techniques that provide measurements of particle size, morphology, fine structure, and elemental and molecular composition, all of which are tied to particle maturity and 
influence reactivity and optical properties. There is a host of powerful ex situ tools for assessing particle size, morphology, and composition; these tools require extractive sampling from the combustor, however, which poses a significant perturbation to the chemistry under study [23-25]. There is thus a need for in situ methods that can provide this type of information. This review will highlight some of the techniques available for in situ measurements, along with their advantages and weaknesses.

\section{Soot chemistry and characteristics}

This section provides a brief outline of soot chemistry as a foundation for the discussion of diagnostic techniques available and needed for studying soot formation and evolution in the combustor.

Figure 1 summarizes the basic chemistry of soot formation and evolution. Small radicals, such as $\mathrm{OH}$, $\mathrm{O}, \mathrm{H}, \mathrm{CH}$, and $\mathrm{CH}_{2}$, play an important role in soot formation, starting from the chemical initiation of combustion and fuel decomposition [26-29]. These small radicals lead to reactions that generate larger hydrocarbon radicals and polycyclic aromatic hydrocarbon (PAH) species known to be precursors to soot formation [26, 27, 30-34].

These PAH precursors nucleate, react and combine, or grow to form incipient ${ }^{*}$ soot particles. Incipient soot particles are freshly nucleated particles with elemental carbon-to-hydrogen $(\mathrm{C} / \mathrm{H})$ ratios in the range of 1.4-2.5 [35-42]. They tend to have significantly more aromatic than aliphatic character [35, 43-45] and may also contain oxygenated species [43, 45-49]. Although not defined by their size, they naturally exist as nanoparticles in the size range of 1-10 $\mathrm{nm}[33,44,50-55]$ and are sometimes referred to as nano-organic carbon (NOC) [56-60].

Experimental evidence suggests that there are at least two types of incipient particles $[51,52,56,57$, 61-65]. The first type (1) absorbs in the UV but is transparent at visible and IR wavelengths [59, 66-70],

\footnotetext{
* The term "nascent" is often used to describe young, freshly nucleated soot particles, but this term is also used within the atmospheric research community to label mature soot freshly emitted from the combustor. "Incipient", an alternative expression for young soot particles, is used here to avoid confusion.
} 
(2) fluoresces predominantly in the $\mathrm{UV}[56,57,71]$, (3) is less than $\sim 3 \mathrm{~nm}$ in diameter $[51,52,56,57$, $62,63,65],(4)$ is formed under relatively fuel-lean conditions [51, 52, 62-65], and (5) appears to be composed of randomly ordered aromatic structures combined with some aliphatic content [51, 52, 64, 65]. This type of particle may be consistent with the macromolecular clusters predicted by Violi and coworkers [72-74] or the particles predicted by Frenklach [34] to be formed by processes that are not entirely thermodynamically controlled. In this review, this type of incipient particle will be referred to as disordered incipient particles.

The second type of incipient particle (1) absorbs in the visible and IR regions [64, 66], (2) fluoresces in the visible $[56,57,64]$, (3) is $\geq \sim 3 \mathrm{~nm}$ in diameter $[33,54,62,63,68,75-77]$, (4) is formed under fuelrich conditions [51, 52, 62-65], and (5) appears to be composed of nucleated [38, 76, 78, 79], stacked $[64,80]$ PAH structures held together by van der Waals forces [64]. This second type of particle may be consistent with structures predicted by Frenklach [34] to be formed at high temperatures by the Habstraction- $\mathrm{C}_{2} \mathrm{H}_{2}$-addition (HACA) driven mechanism, which generates clusters of physically bound stable PAHs. In transmission electron microscopy (TEM) and atomic-force microscopy (AFM) images, these particles appear spherical $[35,54,68,69,75-77]$ and liquid-like $[33,35,76,77,81,82]$. In this review, this type of incipient particle will be referred to as stacked incipient particles. Recent studies using AFM [83] and helium-ion microscopy (HIM) [47] have demonstrated structures that appear to be agglomerated. These observations of a non-spherical structure in AFM and HIM images could be an indication of a third type of incipient particle or may be explained by partial graphitization and agglomeration of small incipient particles.

These incipient particles grow further by coalescence (i.e., merging) and surface addition to become larger primary particles with diameters in the range of $10-50 \mathrm{~nm}[33,75,84,85]$. As these particles grow, they undergo dehydrogenation and start to solidify and coagulate (i.e., agglomerate) rather than coalesce. Additional surface growth of graphitic layers aids final aggregation. Following the definitions 
given by the International Organization of Standardization (ISO), an agglomerate is a collection of particles that are loosely connected, and an aggregate is a collection of particles that are tightly bound.

As the aggregate size grows with particle age, so do the primary-particle size and volume fraction $[75,85,86]$ while the number density decreases or stays nearly constant $[54,87,88]$. The primaryparticle size and volume fraction will decrease during oxidation $[85,86]$. Although the volume fraction and size of mature soot particles depend on fuel type and combustion conditions, their morphology does not $[89,90]$. As long as they reach maturity, they tend to exit the combustor with a fractal dimension in the range of 1.7-1.9, e.g., [91-94].

As soot matures, the $\mathrm{C} / \mathrm{H}$ ratio increases [35, 36, 41, 42, 95-97]; the absorption cross section shifts to longer wavelengths (i.e., the Ångström or dispersion exponent decreases) [66, 95, 98-107]; the optical band gap decreases $[66,96,108-110]$; the graphite crystallite size increases $[95,111,112]$; the interlayer spacing decreases [36, 113, 114]; the fine structure becomes more ordered [84, 95, 113-115], the electrical conductivity increases [83], and the aromatic to aliphatic ratio tends to increase $[35,116,117]$. Although these changes occur over a short distance in the flame, soot can exist over a wide range of levels of maturity, starting from incipient soot, which is at a very early phase in the chemical and physical evolution of the particle. Several studies have shown that, under some conditions, the aliphatic content can increase to the point that it overwhelms the aromatic content $[44,45,118,119]$. These changes in composition are not well understood. Even for simple hydrocarbon fuels, relatively mature soot particles can contain oxygenated functional groups [49].

Whereas incipient and very young soot particles are predominantly composed of condensed aromatic hydrocarbons with $\mathrm{C} / \mathrm{H}$ ratios on the order of 1.4-2.5 [35-42] and generally disordered fine structure [35, $39,95,114,120-122]$, mature soot is composed of "primary" particles 10-50 $\mathrm{nm}$ in diameter with an elemental composition dominated by carbon and $\mathrm{C} / \mathrm{H}$ ratios of $10-20[35,36,41,42,120,123]$. The fine structure of mature primary particles is similar to polycrystalline graphite with graphite-like crystallites 
preferentially aligned parallel to the particle surface near the surface and randomly oriented in the center of the particle [80, 123-128]. The disordered region in the center is approximately 4-6 $\mathrm{nm}$ in diameter [127]. There are some important differences between polycrystalline graphite and soot, however. The graphene layers in graphite are aligned relative to each other along an axis called the $c$-axis, whereas these layers are randomly rotated with respect to each other in soot. This so-called turbostratic structure of soot leads to a larger interlay spacing $(\sim 0.35 \mathrm{~nm})$ for soot than for graphite $(0.335 \mathrm{~nm})[80,97,113$, $123,126,128,129]$ and the electronic structure of a zero-gap semiconductor rather than the semimetal 0.04-eV band overlap of graphite [130]. The primary particles of soot are covalently bound into dendritic aggregates that vary widely in size $[123,125,131,132]$ and are typically characterized by fractal dimensions in the range of 1.7-1.9, e.g., [91-94]. Oxidation of mature soot leads to a reduction in the interlayer spacing [133, 134], primary-particle size, and volume fraction $[85,86]$.

\section{Available diagnostics}

Experimental identification and characterization of soot particles in combustion zones are tremendously important to our understanding of the mechanisms controlling particle formation, growth, and oxidation in combustion systems. Addressing outstanding questions in soot chemistry will require measurements of particle characteristics, such as composition, size, fine structure, morphology, abundance, and distribution, as they evolve during combustion. These measurements will need to be made under a wide range of conditions. Because of space limitations, this review is restricted to a discussion of available in situ diagnostics. There are a number of recent reviews that cover complementary diagnostics and/or a subset of the topics covered here [93, 135-142]. This review provides an update to some of these previous reviews and a complement to others. There are numerous in situ diagnostic methods that have been successfully employed for such studies (see Table 1), enabling the development of the understanding of soot chemistry summarized in Section 2. There is, however, a strong need for additional in situ diagnostics, which minimize perturbations to the combustion 
environment and may enable reliable monitoring of molecular species and particles with high spatial and temporal resolution. This section summarizes these available in situ methods and their advantages and potential disadvantages.

\subsection{Soot volume fraction}

\subsubsection{Spectral soot emission}

There is a long history of soot volume-fraction measurements in flames using spectral soot emission (SSE) techniques based on spectrally resolved or multi-wavelength measurements of passive soot radiative emission [143-160]. Soot temperatures are inferred by fitting the Planck function to the measured spectral signals, assuming a wavelength dependence for the emissivity. Once the particle temperatures are known, the absolute signal magnitude can be used to determine the volume fraction, based on predicted emission rates estimated using the Planck function. For an axisymmetric flame, an Abel inversion is required to infer radial distributions. An advantage of this technique is that it is easily amenable to imaging configurations, including three-dimensional stereoscopic tomography [155]. Use of high-speed cameras allows imaging of soot temperatures and volume fractions in non-steady flames $[146,155]$. It can also be implemented under high-pressure conditions $[146,150,151,160]$. In addition, it does not require lasers or fast detectors, but it does require accurate detector calibration and a firm understanding of the wavelength dependence of the particle emissivity. Uncertainties in the optical properties of particles as they evolve in the flame and self-absorption and scattering in optically thick flames can lead to uncertainties in inferred particle temperatures, which yield large errors in derived volume fractions [149, 157]. Probe volume heterogeneities can also lead to uncertainties [149]. Simultaneous measurements using another technique, such as extinction, can facilitate error reduction $[143,158]$. Figure 2 shows an example of a comparison of soot volume fraction measurements in a coflow diffusion flame using SSE and extinction methods [156]; here the methods agree to within $15 \%$.

\subsubsection{Laser-induced incandescence}


LII has become the most commonly used technique for soot-distribution and volume-fraction measurements of fully mature and nearly mature or partially graphitized soot in combustors [136, 142]. In this application, a (typically nanosecond) pulsed laser is sent into the combustor either as a beam for point or line measurements or as a sheet for two-dimensional imaging measurements. As long as the laser power is high enough that the particles are heated sufficiently to reach the sublimation point, the signal magnitude is approximately linearly proportional to the volume fraction. Because mature soot particles absorb strongly over a broad spectral range and can be readily heated to their sublimation point of $\sim 4000 \mathrm{~K}$, LII is very selective for, and highly sensitive to, mature soot (or at least partially graphitized particles). LII is sensitive enough and fast enough to be used for single-shot measurements in turbulent flames. It can used for high-pressure applications, as long as laser fuences are high enough to enable absorptive heating rates to compete with conductive cooling rates, and detection times are prompt, i.e., occur during the laser pulse [161]. LII has been studied extensively; for more details about the implementation of this technique, the reader is referred to several reviews on this subject, i.e., [136, $142,162]$.

If the conditions are not too optically thick to pass the laser to the detection region and/or signal to the detector, LII can be used to image soot in engine cylinders. Figure 3 shows an example of LII signal generated inside a direct-injection Diesel-engine cylinder [163]. A sheet of 1064-nm laser radiation was passed into the cylinder of an optically accessible engine, and LII signal was collected to the blue of 450 nm. The soot distribution inferred from the LII signal and shown in Fig. 3 is the result of an average over 50 engine cycles.

Quantitative volume-fraction measurements using LII usually require calibration with another technique, such as laser extinction, e.g., [164-178]. In order to calibrate against another optical method, however, the optical properties of the particles must be well known, and the conditions of the calibration, e.g., soot maturity and ambient temperature and pressure, must be similar to those under 
which the LII measurements are made, e.g., [175]. Under high-pressure conditions, conductive cooling competes with absorptive laser heating, even on a nanosecond timescale and can have an influence on the ability to reach and maintain the sublimation temperature [161]. Alternatively, LII can be measured without an explicit calibration procedure if the temperature of the laser-heated particles is inferred from measured radiative emission at two or more wavelengths, and the absolute intensity of the incandescence is also measured [152, 179-182]. For implementation of this technique, the optical properties of the particles need to be well known, and the signal-collection system needs to be well calibrated. This technique is an extension of the method for determining soot volume fraction using multi-wavelength analysis of soot flame luminosity [145, 147, 148, 154].

Detection by LII requires that the particles absorb strongly at the laser wavelength and are refractory, i.e., sufficiently mature and graphitic to be able to be heated to temperatures above $\sim 3500 \mathrm{~K}$ without vaporizing or undergoing photolysis. The types of incipient particles discussed in Section 2 generally do not produce LII signal. Disordered incipient particles do not absorb at typical LII laser wavelengths in the visible and IR [63, 67-69], and are not capable of generating quasi-blackbody radiation because (1) they do not absorb enough energy to reach sufficiently high temperatures to incandesce and (2) their absorption spectrum is inconsistent with blackbody emission without violating Kirchhoff's law of thermal radiation, i.e., detailed balance [183]. Stacked incipient particles can absorb in the visible or IR, but because they are bound by van der Waals forces, they tend to be unstable enough to be destroyed by 1064-nm laser radiation at even moderate intensities [63]. Observations of stacked incipient-particle destruction with 1064-nm radiation [63] are supported by comparisons of LII measurements with SMPS and PIMS measurements of incipient-particle formation, growth, and graphitization [184], which demonstrate distinctions between incipient particles measured by SMPS and PIMS and more mature particles measured by SMPS and LII. Other results have suggested, however, that observable LII signal can be produced by particles that are less than $10 \mathrm{~nm}$ in size [184-189]. 
Temperatures inferred from two-color LII measurements (assuming the optical properties of graphite) indicate that these particles reach the sublimation temperature of mature soot of $~ 4000 \mathrm{~K}$ [188]. Particle sizes inferred from these measurements may be underestimated, however, if they are derived assuming the thermal accommodation coefficient for mature soot $[99,187,190]$. Nevertheless, these results may indicate a type of particle that appears at the size of an incipient-soot particle but has the properties of a graphitized or partially graphitized soot particle. More work is warranted to determine the composition and source of these particles.

Graphitization proceeds rapidly under some flame conditions, however, and LII has been recorded from small particles as they mature [188]. Even for partially graphitized particles, the sublimation temperature, absorption cross section, and emissivity increase with increasing maturity [187, 191]. Thus, mature soot particles will reach higher peak temperatures and emit more radiation than less mature particles of the same mass, introducing a potential bias in LII measurements if the particle maturity is not taken into account. Calibration approaches should therefore account for particle maturity.

\subsubsection{Other techniques}

Other in situ optical techniques that have been demonstrated to yield information about soot abundance include detection of laser-induced $\mathrm{C}_{2}$ Swan-band emission resulting from soot vaporization [192], detection of soot using four-wave mixing [193], and photoacoustic [194] techniques. Thermophoretic particle densitometry is also used to measure soot volume fraction. This technique entails rapidly inserting a thermocouple into a flame; as the soot builds up on the thermocouple, the measured temperature changes. This behavior can be modeled and compared with the rate of soot collection on the thermocouple probe [195-197]. Because this technique involves inserting a probe into the flame, it has drawbacks similar to ex situ sampling techniques and is more intrusive than optical techniques. 
Volume fraction can also be determined using ELS [50, 59, 71, 93, 198, 199] or extinction [200204] in the visible and UV spectral regions. Both techniques are dependent on a firm understanding of the optical properties of the particles for quantitative analysis. Extinction is a line-of-sight or pathintegrated method that measures the combination of total absorption and scattering by the particles. This technique requires an Abel inversion for determining particle distributions in an axisymmetric flame, e.g., [205]. Extinction is very often combined with ELS to determine volume fraction and other particle characteristics, such as aggregate size and morphology [205-208] (see Section 3.2) and optical properties [107] (see Section 3.4). ELS is prone to interferences by other particles, however, and extinction is susceptible to interferences by absorbing gas-phase species. For incipient particles smallangle X-ray scattering (SAXS) or small-angle neutron scattering (SANS) may be options (see Section $3.2)$.

\subsection{Particle size and morphology}

\subsubsection{Light scattering}

Multi-angle and polarized elastic light scattering (ELS) in the visible and IR can be used to extract average primary-particle size and aggregate size and morphology of mature soot particles [93, 209-217]. ELS is typically combined with extinction measurements to yield soot volume fraction, primary-particle size, aggregate size, and fractal dimension [59, 205-208, 218-220]. ELS can similarly be combined with LII to provide such aggregate characterization [221-223].

Because soot aggregates are not spherical, Mie theory cannot be used to provide an exact solution to Maxwell's equations for light scattering. There are approximations, however, to predict light scattering from aggregated particles. When the wavelength of light is much longer than the particle size, the Rayleigh approximation can be invoked. Under typical flame conditions, the primary-particle size is much smaller than visible or near-IR wavelengths, and the primary particles are considered to be in the Rayleigh limit. Because soot aggregates are often outside this limit, other theories have been developed. 
Other popular approximations include the Rayleigh-Debye-Gans (RDG) for fractal aggregates (RDGFA) approximation $[93,211,224-226]$, the discrete-dipole approximation (DDA) [215, 226, 227], and the T-matrix method (TMM) [215, 227].

For incipient particle sizes, it is necessary to extend scattering measurements to shorter wavelengths. Small-angle X-ray scattering (SAXS) is sensitive to regions of high electron density (e.g., particles on a nanometer scale), provides information about average aggregate morphology and size, primary-particle size, and incipient particle size, and has been used to measure incipient and mature particle-size distributions in flames [228-239]. The hard X-ray beam is directed into the flame, and the forward scattering pattern is recorded at angles that are small relative to the propagation direction of the incident beam. Particle-size distributions are inferred from measurements of scattering intensity as a function of scattering angle, which is inversely proportional to the particle size. Performing this analysis is extremely difficult, largely because it is difficult to distinguish particle-induced scattering from scattering related to the gas-phase background, and background subtraction can be complicated. Because temperatures and, hence, gas-phase and particle densities change throughout the flame, the background also varies with location in the flame. Figure 4 presents examples of particle-size distributions measured in a co-flow diffusion flame at different heights above the burner (HABs) [236]. The size distributions indicate the presence of particles spanning a very wide size range from incipient to more mature, larger particles at all HABs. Because the technique involves sending the X-ray beam through the sample, for an axisymmetric flame, such as the co-flow diffusion flame studied, the beam will be scattering from particles that are less mature and smaller in the center of the flame and more mature and larger at the edges. A multi-modal or broad size distribution is thus not alarming. There is some evidence that bombarding soot particles with hard X-rays can lead to particle destruction [240].

\subsubsection{Neutron scattering}


Small-angle neutron scattering (SANS) is complementary to SAXS and can also provide information about incipient and aggregate particle size and morphology [81,233, 241]. Advantages of SANS over SAXS include better discrimination against background air scattering, longer wavelengths (0.4-3 nm), lower absorption, better penetration into dense samples, and less tendency to ionize or damage samples [233]. On the other hand, SANS tends to have lower intensity and lower spatial resolution than SAXS [233]. Figure 5 shows particle-size distributions inferred from SANS measurements in the same flame used for the SAXS measurements shown in Fig. 4. One explanation for the larger sizes inferred for the SANS results than for the SAXS results is that the neutron beam was much larger than the SAXS beam and thus sampled larger particles closer to the edge of the flame [236]. Reasons for the differences between the two techniques at small particle sizes are not clear but may have to do with differences in the range in scattering angles recorded in the two experiments.

\subsubsection{Laser-induced incandescence}

Time-resolved pulsed-LII measurements have been used extensively to infer primary-particle sizes, e.g., [136, 142, 242] and references therein. LII signal-decay rates depend predominantly on the conductive-cooling rates at laser fluences at which particles do not reach the sublimation point. At higher fluences, the signal-decay rate is dominated by mass loss and cooling by sublimation. Primaryparticle sizes are typically inferred from measured LII temporal profiles using an energy- and massbalance model to fit the data with the primary-particle size as an adjustable parameter. Figure 6 summarizes pictorially most of the particle heating, cooling, and mass-loss mechanisms included in LII models [142]. Not all of these processes are included in all models, and some processes are more important than others in determining particle heating and cooling rates [242]. Particles are heated by laser absorption, surface oxidation, and annealing and are cooled by conduction to the surrounding atmosphere, radiative emission, thermionic emission, and sublimation of molecular carbon clusters. Particles lose mass by sublimation and oxidation $[161,242]$. The rate of radiative emission determines 
the signal and, for a Rayleigh particle (small compared to the wavelength of emitted light), is approximately linearly proportional to the mass of the particle and nonlinearly proportional to its temperature (i.e., $\sim T^{5}$ ).

This technique is based on the assumptions that (1) the signal decay rate depends predominantly on the conductive-cooling rate at atmospheric and higher pressure, (2) the conductive-cooling rate is controlled by the primary-particle size, and (3) the processes involved in conductive cooling and relevant parameters and conditions are known well enough to be modeled. The analysis can be complicated by unknown and variable ambient pressure and temperature and signal trapping in optically thick conditions. In addition, there are other factors that can have an influence on LII signals and signal decay rates, including aggregate size [243-252], aggregate morphology [244, 253], polydispersity of primary-particle size [250-252, 254-257], and soot-maturity effects on thermal-accommodation coefficients $[99,190]$. In addition, detection wavelengths must be selected carefully to avoid numerous potential interferences [258, 259]. Nevertheless, considerable work performed by many members of the LII community has led to great advances in improving the utility of this technique under a wide range of conditions. An example of this approach is shown in Fig. 7. Figure 7a shows normalized temporal profiles measured at selected HABs in a premixed flat ethylene-air flame [187]. Decay rates decrease with increasing $\mathrm{HAB}$, indicating increasing particle size with increasing $\mathrm{HAB}$. Figure $7 \mathrm{~b}$ shows primary-particle sizes inferred from LII data compared with results derived from TEM analysis. For aggregates, the primary-particle inferred from LII signal decays sizes over-predict values from TEM analysis, unless aggregation is taken into account [187].

\subsection{Particle composition, fine structure, electronic structure, and optical properties}

\subsubsection{Laser-induced fluorescence}

Compared to the broad range of ex situ measurement approaches available for studies of particle composition, there are relatively few in situ techniques available for measuring particle composition. 
Use of laser-induced fluorescence (LIF) to provide compositional information has been attempted; although the spectra are broad and do not provide detailed information about specific species or functional-groups, large shifts in spectral maxima have been used to distinguish groups of particles with significant differences in aromatic constituent sizes $[50,64,66,67,71,260]$. Fluorescence lifetime measurements coupled with fluorescence spectral measurements have been useful for supporting conclusions about incipient particle structures derived from ex situ spectroscopic measurements [64].

\subsubsection{UV-visible spectroscopy and light extinction}

There are dramatic changes in the wavelength dependence of the absorption cross section of soot particles in the UV, visible, and IR spectral regions as the particles evolve during combustion. Incipient soot particles often absorb strongly in the UV and are transparent, or nearly so, at longer wavelengths [59, 67-70], as shown by the circles in Fig. 8. Many studies have demonstrated an increase and a shift to longer wavelengths of the absorption or extinction coefficient with increasing particle maturity [66, 95, 98-106], as demonstrated by the squares and diamonds in Fig. 8. Another example of this phenomenon is provided in Fig. 9, which shows normalized absorption spectra recorded at selected heights HABs in an ethylene-air premixed flame [98]. With increasing HAB, particle maturity increases, and the relative absorption shifts to longer wavelengths. The increase in extinction with maturity is not demonstrated in this figure because the spectra have been normalized to each other.

The dispersion exponent is a measure of this change in wavelength dependence of the absorption cross section, which can be expressed for a spherical Rayleigh particle with diameter $d$ as

$$
{ }_{a b s}=\frac{d^{3}}{6}-
$$

where $\lambda$ is the wavelength of light, $\xi$ is the dispersion or Ångström exponent, and $\beta$ is a scaling factor. The dispersion exponent decreases as the particle matures and the $\mathrm{C} / \mathrm{H}$ ratio increases. If soot can be described as a semi-conductor, its optical properties can be expressed in terms of an optical band gap 
$[66,67]$. Minutolo, D'Alessio, and coworkers $[66,67]$ used the Tauc formula to estimate the optical band gap, i.e.,

$$
\left(C_{a b s} E\right)^{1 / r}=B\left(\begin{array}{ll}
E & E_{T}
\end{array}\right)
$$

where $E$ is the photon energy, $E_{T}$ is the Tauc optical band gap, $B$ is a constant, $r$ is a parameter associated with the type of band gap transition [108, 261], and $C_{a b s}$ is the absorption coefficient given by

$$
C_{a b s}=\left(\frac{d^{3}}{6}\right)^{1} .
$$

For $r$ Miller and coworkers $[108,261]$ use a value of 0.5 , which is appropriate for an allowed, direct band gap whereas other researchers $[65-67,83,96]$ have used a value of 2 , which corresponds to an allowed, indirect band gap. The band gap can then be derived from UV and visible absorption spectra by plotting $\left(C_{a b s} E\right)^{1 / r}$ vs $E$ and fitting a line to the data to determine the intercept. The dispersion exponent has been shown to be approximately linearly dependent on the $\mathrm{C} / \mathrm{H}$ ratio [262], and the dispersion exponent and $\mathrm{C} / \mathrm{H}$ ratio are both correlated with the optical band gap [66]. Thus, any technique that provides a measure of the wavelength dependence of the absorption cross section can yield information about the dispersion exponent, optical band gap, and $\mathrm{C} / \mathrm{H}$ ratio [66], all of which can be exploited to provide information about soot maturity and graphitization [65, 67, 96, 108-111, 120, 261]. Miller and coworkers [108, 261, 263] have extended this analysis using Tauc/Davis-Mott analysis to facilitate estimates of sizes of PAHs in soot particles by deriving the relationship between the optical band gap and the number of aromatic rings $M$ in a cluster, i.e.,

$$
E_{T}=\frac{5.8076}{M^{1 / 2}}+0.5413
$$

Wavelength-resolved light-extinction measurements in the UV and visible regions, i.e., UV-visible spectroscopy, can provide information about the dispersion exponent or optical band gap and thus maturity, e.g., [67]. This approach relies on assumptions about scattering, however, which can be 
significant and difficult to take into account. In addition, both the scattering contribution and particle maturity can vary substantially along the measurement path, complicating the interpretation. Interferences by gas-phase species absorption can also perturb the measurement $[98,110]$. With respect to optical properties, wavelength-resolved light-extinction measurements in the visible and IR regions have also been used extensively to infer the complex index of refraction, e.g., [104, 264-267].

\subsubsection{Laser-induced incandescence and elastic light scattering}

In contrast to extinction, which includes contributions from scattering and absorption, LII is directly dependent on the absorption cross section of soot particles and is not path integrated and can be used to infer information about soot maturity. Such information can be derived from LII measurements made using multiple laser wavelengths in the visible and/or IR [99, 268, 269]. UV laser wavelengths are less effective for LII because they are plagued by potential interferences from gas-phase flame species [142] and tend to lead to soot particle photolysis [270, 271]. Figure 10 shows maxima of the LII temporal profiles (i.e., peak LII) plotted as a function of laser fluence [99]. As fluence increases, the peak LII increases until the incandescing soot particles reach the sublimation point, and the peak LII saturates. Peak LII fluence curves are shown for two regions of a co-flow diffusion flame. In the center of the flame, the particles are less mature, the absorption cross sections are smaller, and the fluence curves are shifted to higher fluences at each laser wavelength, i.e., it takes more laser energy to heat the particles because the absorptive heating rate is lower. The peaks are shifted more at $1064 \mathrm{~nm}$ than at $532 \mathrm{~nm}$, which is an indication that the absorption cross section drops more at $1064 \mathrm{~nm}$ than at $532 \mathrm{~nm}$ for less mature particles in the center of the flame. This behavior is the result of a higher dispersion exponent for less mature soot, which has been demonstrated in numerous studies [66, 95, 98, 99, 101-107]. Approaches combining LII with extinction [100], LII with ELS [191], or ELS with extinction [66, 107] similarly yield information about soot maturity. Most of these techniques can be used to determine the dispersion exponent or optical band gap, thereby providing information about soot maturity. They can 
thus be used as indirect methods to measure soot maturity, but the compositional information is very limited.

Whereas LII is a direct measure of the absorption cross section, ELS is a direct measure of the scattering cross section. These techniques can be combined to derive the complex index of refraction, or multi-angle ELS can be used to infer the complex index of refraction directly, e.g., [211, 266, 272, 273$].$ Alternatively, ELS can be combined with extinction measurements to derive the refractive index, e.g., [274-277].

\subsubsection{Wide-angle X-ray scattering}

Wide-angle X-ray scattering (WAXS) [235, 238, 278-280] complements SAXS with insight into the particle fine structure and can provide information about soot maturity. As with SAXS, data interpretation and analysis can be involved and complicated. WAXS studies have demonstrated that lower temperature combustion conditions yield more graphitic structures whereas higher combustion temperatures generate more curved, less ordered structures [235, 238, 278-280].

\subsubsection{X-ray absorption spectroscopy}

In order to capitalize on powerful X-ray absorption techniques, a few attempts have been made to implement such techniques in situ in flames. Figure $11 \mathrm{~b}$ shows an example of a NEXAFS spectrum taken in a non-sooting low-pressure methane jet flame [281]. The largest peaks observed are attributable to the gas-phase species $\mathrm{CO}, \mathrm{CO}_{2}$, and $\mathrm{CH}_{4}$, which are shown individually in Fig. 11a. In this study, a soft X-ray beam was transmitted though the flame, and the transmittance was measured. The results are

promising for extending the technique to sooting flames, but the use of soft X-rays limits the experiments to low-pressure flames. X-ray induced ionization has also been used as a proxy for X-ray absorption for in situ studies of sooting flames [282, 283]. These studies were performed with hard Xrays that could be propagated through a flame at atmospheric pressure.

\section{Diagnostics needs}


There are numerous unanswered questions related to soot formation and evolution during combustion. Many of the uncertainties associated with soot chemistry are attributable to a paucity of adequate diagnostic tools for particle characterization. Development of diagnostics for incipient particles is particularly difficult, but there is plenty of room for advancement in every sub-field of soot diagnostics.

In addition to the diagnostic needs for particle characterization, there is a critical need for supplementary diagnostics for important parameters relevant to the combustion environment in which the particles evolve. These parameters include temperature, pressure, flow fields, and gas-phase combustion constituents. For in situ measurements, one exciting recent development has been made in implementing coherent anti-Stokes Raman spectroscopy (CARS) for measurements of temperatures and abundances of small gas-phase species under sooting conditions. An example is shown in Fig. 12 for a fuel-rich ethylene-air premixed flat flame in which femtosecond two-beam phase matching was used to achieve single-shot images of spectra yielding temperature and relative concentrations of $\mathrm{N}_{2}$ and $\mathrm{O}_{2}$ in a sooting flame [284]. In situ measurements of $\mathrm{OH}$ [113, 285-287], $\mathrm{CH}$ [288], $\mathrm{CH}_{2} \mathrm{O}$ [289-291], and $\mathrm{PAH}$ [113, 285, 287, 291-304] distributions have been accomplished using laser-induced fluorescence (LIF) [113, 285-289, 291, 294-300, 302-304] or absorption spectroscopy [292-294, 301]. Although characterization of the combustion environment is critically important for gaining insight into factors that influence soot evolution, a full review of available diagnostics for such supporting measurements is beyond the scope of the current review. The interested reader can find more information about these diagnostics in several recent reviews [139, 140, 305-309].

Because this review is focused on in situ diagnostics available for probing basic soot chemistry, and because much of the fundamental experimental work related to studies of soot chemistry is performed on laminar flames, this review has predominantly addressed diagnostics development for these relatively simple combustion systems. There is, however, a very pressing need for (1) diagnostics that allow 
single-shot measurements for turbulent systems, (2) methods that are feasible for measurements under high and evolving pressure and optically dense conditions, e.g., engine conditions, (3) techniques that can be applied to rapidly evolving biomass-burning events, i.e., wildfires, and (4) diagnostics that are non-invasive to the combustion system under study. In general, advances can be made in combining available techniques, collaborating across disciplines and sub-fields to develop and apply new techniques, making multiple measurements on the same system, and forming strong working relationships between experimentalists and modelers.

\section{Acronyms and abbreviations}

$\begin{array}{ll}\mathrm{AFM} & \text { atomic force microscopy } \\ \mathrm{C}_{2} & \text { diatomic carbon } \\ \mathrm{CH} & \text { methylidyne radical } \\ \mathrm{CH}_{2} & \text { methylene } \\ \mathrm{CH}_{2} \mathrm{O} & \text { formaldehyde } \\ \mathrm{CO} & \text { carbon monoxide } \\ \mathrm{CO} & \text { carbon dioxide } \\ \mathrm{DDA} & \text { discrete-dipole approximation } \\ D(R) & \text { Particle volume distribution function for SAXS } \\ \mathrm{ELS} & \text { elastic light scattering } \\ \mathrm{H} & \text { hydrogen atom } \\ \mathrm{HAB} & \text { height above the burner } \\ \mathrm{HACA} & \text { H-abstraction- }{ }_{2} \mathrm{H}_{2} \text {-addition } \\ \mathrm{HIM} & \text { helium-ion microscopy } \\ \mathrm{IR} & \text { infrared } \\ \mathrm{LIF} & \text { International Organization of Standardization } \\ & \text { laser-induced fluorescence } \\ \mathrm{H} & \end{array}$




\begin{tabular}{|c|c|}
\hline MBMS & molecular-beam mass spectrometry \\
\hline MS & mass spectrometry \\
\hline NEXAFS & near-edge X-ray absorption fine structure \\
\hline $\mathrm{NO}_{2}$ & nitrogen dioxide \\
\hline $\mathrm{O}$ & oxygen atom \\
\hline $\mathrm{O}_{2}$ & molecular oxygen \\
\hline $\mathrm{O}_{3}$ & ozone \\
\hline $\mathrm{OH}$ & hydroxyl radical \\
\hline PAH & polycyclic aromatic hydrocarbon \\
\hline PIMS & photoionization mass spectrometry \\
\hline PIV & particle-image velocimetry \\
\hline$P(R)$ & Particle volume distribution function for SANS \\
\hline RDG & Rayleigh-Debye-Gans \\
\hline RDG-FA & Rayleigh-Debye-Gans for fractal aggregates \\
\hline SANS & small-angle X-ray scattering \\
\hline SAXS & small-angle neutron scattering \\
\hline SMPS & scanning mobility particle sizer \\
\hline SSE & soot spectral emission \\
\hline $\mathrm{SO}_{2}$ & sulfur dioxide \\
\hline TEM & transmission electron microscopy \\
\hline TMM & T-matrix method \\
\hline UV & ultraviolet \\
\hline WAXS & wide-angle X-ray scattering \\
\hline
\end{tabular}

I am very grateful to Profs. Peter Glarborg and Assad Masri for inviting me to give this Topical Review Lecture and write the associated review paper. I thank Dr. K. Olof Johansson for help generating Fig. 1 
and for insightful comments, Prof. Hai Wang, Dr. Matthew Campbell, Dr. Farid El Gabaly, and Prof.

Houston Miller for carefully reading this manuscript and making very helpful suggestions, and Dr. Chris

Shaddix for sharing his references on radiative-heat transfer with me. This work was funded by the

Division of Chemical Sciences, Geosciences, and Biosciences, the Office of Basic Energy Sciences, the

US Department of Energy. Sandia National Laboratories is a multi-program laboratory managed and

operated by Sandia Corporation, a wholly owned subsidiary of Lockheed Martin Corporation, for the

DOE’s National Nuclear Security Administration under contract DE-AC04-94AL85000.

\section{References}

[1] A.F. Sarofim, Twenty-firs Symposium (International) on Combustion 1 (1986) 1-23.

[2] R. Viskanta, M.P. Mengüc, Prog. Energy Combust. Sci. 13 (1987) 97-160.

[3] J.F. Sacadura, J. Quant. Spectrosc. Radiat. Transfer 93 (2005) 5-24.

[4] R. Viskanta, International Journal of Thermal Sciences 47 (2008) 1563-1570.

[5] J. Benajes, J. Martín, A. García, D. Villalta, A. Warey, Energy Conversion \& Management 106 (2015) 414-427.

[6] J.S. Lighty, J.M. Veranth, A.F. Sarofim, J. Air Waste Manage. Assoc. 50 (9) (2000) 1565-1618.

[7] M. Lippmann, Critical Reviews in Toxicology 44 (4) (2014) 299-347.

[8] N.A.H. Janssen, G. Hoek, M. Simic-Lawson, P. Fischer, L. van Bree, H. ten Brink, M. Keuken, R.W. Atkinson, H.R. Anderson, B. Brunekreef, F.R. Cassee, Environ. Health Perspect. 119 (12) (2011) 1691-1699.

[9] L.E. Murr, K.M. Garza, Atmos. Environ. 43 (2009) 2683-2692.

[10] E.J. Highwood, R.P. Kinnersley, Environ. Int. 32 (2006) 560-566.

[11] IPCC, Climate Change 2013: The Physical Science Basis. Working Group I Contribution to the Fifth Assessment Report of the Intergovernmental Panel on Climate Change, ed. T.F. Stocker, et al. 2013, Cambridge, UK and New York, NY: Cambridge University Press.

[12] T.C. Bond, S.J. Doherty, D.W. Fahey, P.M. Forster, T. Berntsen, B.J. DeAngelo, M.G. Flanner, S. Ghan, B. Kärcher, D. Koch, S. Kinne, Y. Kondo, P.K. Quinn, M.C. Sarofim, M.G. Schultz, M. Schulz, C.

Venkataraman, H. Zhang, S. Zhang, N. Bellouin, S.K. Guttikunda, P.K. Hopke, M.Z. Jacobson, J.W. Kaiser, Z. Klimont, U. Lohmann, J.P. Schwarz, D. Shindell, T. Storelvmo, S.G. Warren, C.S. Zender, J. Geophys. Res. Atmos. 118 (11) (2013) 5380-5552.

[13] B.R. Stanmore, V. Tschamber, J.-F. Brilhac, Fuel 87 (2008) 131-146.

[14] B.J. Finlayson-Pitts, J.N. Pitts, Jr., Chemistry of the Upper and Lower Atmosphere. 2000, San Diego: Academic Press.

[15] U. Kirchner, V. Scheer, R. Vogt, J. Phys. Chem. A 104 (2000) 8908-8915.

[16] A.M. Nienow, J.T. Roberts, Annu. Rev. Phys. Chem. 57 (2006) 105-128.

[17] H.A. Al-Abadleh, V.H. Grassian, J. Phys. Chem. A 104 (2000) 11926-11933.

[18] B.G. Koehler, V.T. Nicholson, H.G. Roe, E.S. Whitney, Journal of Geophysical Research-Atmospheres 104 (D5) (1999) 5507-5514.

[19] M. Antiñolo, M.D. Willis, S. Zhou, J.P.D. Abbatt, Nature Communications 6 (2015) 6812.

[20] E.C. Browne, J.P. Franklin, M.R. Canagaratna, P. Massoli, T.W. Kirchstetter, D.R. Worsnop, K.R. Wilson, J.H. Kroll, J. Phys. Chem. A 119 (2015) 1154-1163. 
[21] S. Lelièvre, Y. Bedjanian, N. Pouvesle, J.-L. Delfau, C. Vovelle, G. Le Bras, Phys. Chem. Chem. Phys. 6 (2004) 1181-1191.

[22] DOE, Report of the Basic Energy Sciences Workshop on Basic Research Needs for Clean and Efficient Combustion of 21st Century Transportation Fuels, O.o. Science, Editor. 2006.

[23] A. De Filippo, L.A. Sgro, G. Lanzuolo, A. D'Alessio, Combust. Flame 156 (2009) 1744-1754.

[24] F.X. Ouf, J. Yon, P. Ausset, A. Coppalle, M. Maillé, Aerosol Sci. Technol. 44 (11) (2010) 1005-1017.

[25] C. Saggese, A. Cuoci, A. Frassoldati, S. Ferrariio, J. Camacho, H. Wang, T. Faravelli, Combust. Flame 167 (2016) 184-197.

[26] C.S. McEnally, L.D. Pfefferle, B. Atakan, K. Kohse-Höinghaus, Prog. Energy Combust. Sci. 32 (3) (2006) 247294.

[27] H.F. Calcote, Combust. Flame 42 (1981) 215-242.

[28] A. Bhargava, P.R. Westmoreland, Combust. Flame 115 (1998) 456-467.

[29] P.F. Jessen, A.G. Gaydon, Twelfth Symposium (International) on Combustion 12 (1969) 481-489.

[30] H. Bockhorn, ed. Soot Formation in Combustion: Mechanisms and Models. Chem. Phys., ed. V.I. Goldanskii, F.P. Schäfer, and J.P. Toennies. Vol. 59. 1994, Springer-Verlag: Berlin. 596.

[31] H. Richter, J.B. Howard, Prog. Energy Combust. Sci. 26 (2000) 565-608.

[32] K.-H. Homann, Angew. Chem. Int. Ed. 37 (1998) 2434-2451.

[33] H. Wang, Proc. Combust. Inst. 33 (2011) 41-67.

[34] M. Frenklach, Phys. Chem. Chem. Phys. 4 (11) (2002) 2028-2037.

[35] C. Russo, A. Tregrossi, A. Ciajolo, Proc. Combust. Inst. 35 (2015) 1803-1809.

[36] A. Ciajolo, R. Barbella, A. Tregrossi, L. Bonfanti, Twenty-Seventh Symp. (Internat.) Combust. 27 (1) (1998) 1481-1487.

[37] A. D'Alessio, A. D'Anna, A. D'Orsi, P. Minutolo, R. Barbella, A. Ciajolo, Twenty-Fourth Symp. (Internat.) Combust. 24 (1) (1992) 973-980.

[38] L.G. Blevins, R.A. Fletcher, W.H. Benner, Jr., E.B. Steele, G.W. Mulholland, Proc. Combust. Inst. 29 (2002) 2325-2333.

[39] R.A. Dobbins, H. Subramanian, Soot precursors: Particles in flames, in Soot Formation in Combustion, H. Bockhorn, Editor. 1994, Springer-Verlag: Berlin. p. 290-301.

[40] K.-H. Homann, H.G. Wagner, Eleventh Symp. (Internat.) Combust. 11 (1) (1967) 371-379.

[41] S.J. Harris, A.M. Weiner, Annu. Rev. Phys. Chem. 36 (1985) 31-52.

[42] J.B. Howard, Twenty-Third Symp. (Internat.) Combust. 23 (1) (1990) 1107-1127.

[43] J.P. Cain, A. Laskin, M.R. Kholghy, M.J. Thomson, H. Wang, Phys. Chem. Chem. Phys. 16 (2014) 2586225875.

[44] B. Öktem, M.P. Tolocka, B. Zhao, H. Wang, M.V. Johnston, Combust. Flame 142 (2005) 364-373.

[45] J.T. McKinnon, E. Meyer, J.B. Howard, Combust. Flame 105 (1996) 161-166.

[46] G. Rusciano, A.C. De Luca, A. D'Alessio, P. Minutolo, G. Pesce, A. Sasso, Carbon 46 (2) (2008) 335-341.

[47] M. Schenk, S. Lieb, H. Vieker, A. Beyer, A. Gölzhäuser, H. Wang, K. Kohse-Höinghaus, Proc. Combust. Inst. 35 (2) (2015) 1879-1886.

[48] S.A. Skeen, H.A. Michelsen, K.R. Wilson, D.M. Popolan, A. Violi, N. Hansen, J. Aerosol Sci. 58 (2013) 86-102.

[49] K.O. Johansson, T. Dillstrom, M. Monti, F. El Gabaly, M.F. Campbell, P.E. Schrader, D.M. Popolan-Vaida, N.K. Richards-Henderson, K.R. Wilson, A. Violi, H.A. Michelsen, Proc. Natl. Acad. Sci. U. S. A. (2016) in press.

[50] P. Minutolo, G. Gambi, A. D'Alessio, S. Carlucci, Atmos. Environ. 33 (1999) 2725-2732.

[51] M. Commodo, G. Tessitore, G. De Falco, A. Bruno, P. Minutolo, A. D'Anna, Proc. Combust. Inst. 35 (2015) 1795-1802.

[52] M. Commodo, L.A. Sgro, P. Minutolo, A. D'Anna, J. Phys. Chem. A 117 (2013) 3980-3989.

[53] M. Frenklach, H. Wang, Twenty-Third Symp. (Internat.) Combust. 23 (1990) 1559-1566.

[54] A.D. Abid, N. Heinz, E.D. Tolmachoff, D.J. Phares, C.S. Campbell, H. Wang, Combust. Flame 154 (2008) 775788.

[55] H.H. Grotheer, H. Pokorny, K.-L. Barth, M. Thierley, M. Aigner, Chemosphere 57 (2004) 1335-1342.

[56] A. Bruno, C. de Lisio, P. Minutolo, A. D'Alessio, Combust. Flame 151 (2007) 472-481. 
[57] A. Bruno, C. de Lisio, P. Minutolo, A. D'Alessio, Journal of Optics A: Pure and Applied Optics 8 (2006) S578S584.

[58] G. Rusciano, G. Cerrone, A. Sasso, A. Bruno, P. Minutolo, Appl. Phys. B 82 (2006) 155-160.

[59] A. D'Anna, A. Rolando, C. Allouis, P. Minutolo, A. D'Alessio, Proc. Combust. Inst. 30 (2005) 1449-1456.

[60] S.L. Fiedler, S. Izvekov, A. Violi, Carbon 45 (2007) 1786-1794.

[61] T.G. Baquet, H.H. Grotheer, M. Aigner, Rapid Commun. Mass Spectrom. 21 (2007) 4060-4064.

[62] H.H. Grotheer, K. Hoffmann, K. Wolf, S. Kanjarkar, C. Wahl, M. Aigner, Combust. Flame 156 (2009) 791-800.

[63] H.H. Grotheer, K. Wolf, K. Hoffmann, Appl. Phys. B 104 (2011) 367-383.

[64] M. Sirignano, A. Collima, M. Commodo, P. Minutolo, A. D'Anna, Combust. Flame 159 (2012) 1663-1669.

[65] M. Commodo, G. De Falco, A. Bruno, C. Borriello, P. Minutolo, A. D'Anna, Combust. Flame 162 (2015) 38543863.

[66] P. Minutolo, G. Gambi, A. D'Alessio, Proc. Combust. Inst. 26 (1996) 951-957.

[67] A. D'Alessio, A. D'Anna, G. Gambi, P. Minutolo, J. Aerosol Sci. 29 (4) (1998) 397-409.

[68] L.A. Sgro, A.C. Barone, M. Commodo, A. D'Alessio, A. De Filippo, G. Lanzuolo, P. Minutolo, Proc. Combust. Inst. 32 (2009) 689-696.

[69] L.A. Sgro, G. Basile, A.C. Barone, A. D'Anna, P. Minutolo, A. Borghesi, A. D'Alessio, Chemosphere 51 (2003) 1079-1090.

[70] G. Basile, A. Rolando, A. D'Alessio, A. D'Anna, P. Minutolo, Proc. Combust. Inst. 29 (2002) 2391-2397.

[71] L.A. Sgro, P. Minutolo, G. Basile, A. D'Alessio, Chemosphere 42 (2001) 671-680.

[72] A. Violi, Combust. Flame 139 (2004) 279-287.

[73] S.H. Chung, A. Violi, Carbon 45 (2007) 2400-2410.

[74] A. Violi, A. Venkatnathan, J. Chem. Phys. 125 (2006) 054302.

[75] R.A. Dobbins, C.M. Megaridis, Langmuir 3 (1987) 254-259.

[76] R.A. Dobbins, Aerosol Sci. Technol. 41 (5) (2007) 485-496.

[77] M.M. Maricq, J. Aerosol Sci. 40 (2009) 844-857.

[78] R.A. Dobbins, R.A. Fletcher, H.-C. Chang, Combust. Flame 115 (1998) 285-298.

[79] R.A. Dobbins, R.A. Fletcher, W. Lu, Combust. Flame 100 (1995) 301-309.

[80] H.X. Chen, R.A. Dobbins, Combust. Sci. Technol. 159 (2000) 109-128.

[81] B. Zhao, K. Uchikawa, H. Wang, Proc. Combust. Inst. 31 (2007) 851-860.

[82] M.R. Kholghy, M. Saffaripour, C. Yip, M.J. Thomson, Combust. Flame 160 (2013) 2119-2130.

[83] G. De Falco, M. Commodo, C. Bonavolonta, G.P. Pepe, P. Minutolo, A. D'Anna, Combust. Flame 161 (2014) 3201-3210.

[84] R.L. Vander Wal, V.M. Bryg, C.-H. Huang, Combust. Flame 161 (2014) 602-611.

[85] R. Puri, T.F. Richardson, R.J. Santoro, R.A. Dobbins, Combust. Flame 92 (1993) 320-333.

[86] C.M. Megaridis, R.A. Dobbins, Combust. Sci. Technol. 66 (1989) 1-16.

[87] A.D. Abid, J. Camacho, D.A. Sheen, H. Wang, Combust. Flame 156 (2009) 1862-1870.

[88] J. Camacho, C. Liu, C. Gu, H. Lin, Z. Huan, Q. Tang, X. You, C. Saggese, Y. Li, H. Jung, L. Deng, I. Wlokas, H. Wang, Combust. Flame 162 (2015) 3810-3822.

[89] Ü.Ö. Köylü, G.M. Faeth, T.L. Farias, M.G. Carvalho, Combust. Flame 100 (1995) 621-633.

[90] Ü.Ö. Köylü, Y.C. Xing, D.E. Rosner, Langmuir 11 (12) (1995) 4848-4854.

[91] T.T. Charalampopoulos, H. Chang, Combust. Flame 87 (1991) 89-99.

[92] C. Oh, C.M. Sorensen, J. Colloid Interface Sci. 193 (1997) 17-25.

[93] C.M. Sorensen, Aerosol Sci. Technol. 35 (2001) 648-687.

[94] P. Gwaze, O. Schmid, H.J. Annegarn, M.O. Andreae, J. Huth, G. Helas, J. Aerosol Sci. 37 (2006) 820-838.

[95] M. Alfë, B. Apicella, R. Barbella, J.-N. Rouzaud, A. Tregrossi, A. Ciajolo, Proc. Combust. Inst. 32 (2009) 697704.

[96] A. Tregrossi, A. Ciajolo, Combust. Sci. Technol. 182 (2010) 683-691.

[97] R.H. Muñoz, T.T. Charalampopoulos, Twenty-Seventh Symp. (Internat.) Combust. 27 (1) (1998) 1471-1479.

[98] F. Migliorini, K.A. Thomson, G.J. Smallwood, Appl. Phys. B 104 (2) (2011) 273-283.

[99] X. López-Yglesias, P.E. Schrader, H.A. Michelsen, J. Aerosol Sci. 75 (2014) 43-64. 
[100] M. Leschowski, K.A. Thomson, D.R. Snelling, C. Schulz , G.J. Smallwood, Appl. Phys. B 119 (2015) 685-696. [101] J. Manin, L.M. Pickett, S.A. Skeen, SAE Int. J. Engines 6 (4) (2013) 1908-1921.

[102] A. D'Alessio, F. Beretta, C. Venitozzi, Combust. Sci. Technol. 5 (1972) 263-272.

[103] W.H. Dalzell, A.F. Sarofim, Journal of Heat Transfer, Transactions of the ASME 91 (1969) 100-104.

[104] Z.G. Habib, P. Vervisch, Combust. Sci. Technol. 59 (1988) 261-274.

[105] R.G. Siddall, I.A. McGrath, Proc. Combust. Inst. 9 (1963) 102-110.

[106] J. Simonsson, N.-E. Olofsson, S. Török, P.-E. Bengtsson, H. Bladh, Appl. Phys. B 119 (4) (2015) 657-667.

[107] B. Ma, M.B. Long, Appl. Phys. B 117 (2014) 287-303.

[108] E.M. Adkins, J.H. Miller, Phys. Chem. Chem. Phys. 17 (2015) 2686-2695.

[109] M.L. Botero, E.M. Adkins, S. González-Calera, J.H. Miller, M. Kraft, Combust. Flame 2016 (2016) 250-258.

[110] E.K.Y. Yapp, R.I.A. Patterson, J. Akroyd, S. Mosbach, E.M. Adkins, J.H. Miller, M. Kraft, Combust. Flame 167 (2016) 320-334.

[111] J.D. Herdman, B.C. Connelly, M.D. Smooke, M.B. Long, J.H. Miller, Carbon 49 (2011) 5298-5311.

[112] K. Hayashida, S. Nagaoka, H. Ishitani, Fuel 128 (2014) 148-154.

[113] C.R. Shaddix, T.C. Williams, L.G. Blevins, R.W. Shefer, Proc. Combust. Inst. 30 (2005) 1501-1508.

[114] B. Apicella, P. Pré, M. Alfè, A. Ciajolo, V. Gargiulo, C. Russo, A. Tregrossi, D. Deldique, J.-N. Rouzaud, Proc. Combust. Inst. 35 (2015) 1895-1902.

[115] R.L. Vander Wal, V.M. Bryg, C.-H. Huang, Fuel 115 (2014) 282-287.

[116] A. Santamaria, F. Mondragón, A. Molina, N.D. Marsh, E.G. Eddings, A.F. Sarofim, Combust. Flame 146 (2006) 52-62.

[117] A. Santamaria, N.Y.C. Yang, E.G. Eddings, F. Mondragón, Combust. Flame 157 (2010) 33-42.

[118] J.P. Cain, P.L. Gassman, H. Wang, A. Laskin, Phys. Chem. Chem. Phys. 12 (2010) 5206-5218.

[119] S. di Stasio, A. Braun, Energy Fuels 20 (2006) 187-194.

[120] C. Russo, M. Alfé, J.-N. Rouzaud, F. Stanzione, A. Tregrossi, A. Ciajolo, Proc. Combust. Inst. 34 (2013) 18851892.

[121] B.S. Haynes, H.G. Wagner, Prog. Energy Combust. Sci. 7 (1981) 229-273.

[122] H. Seong, S. Choi, K. Lee, International Journal of Automotive Technology 15 (2) (2014) 175-181.

[123] H.B. Palmer, C.F. Cullis, The formation of carbon from gases, in Chem. Phys. Carbon. 1965, Marcel Dekker, Inc.: New York. p. 265-325.

[124] J. Lahaye, G. Prado, Morphology and internal structure of soot and carbon blacks, in Particulate carbon: Formation during combustion, S. D.C. and G.W. Smith, Editors. 1981, Plenum: New York. p. 33-35.

[125] Ü.Ö. Köylü, G.M. Faeth, Combust. Flame 89 (1992) 140-156.

[126] R.L. Vander Wal, Combust. Sci. Technol. 126 (1997) 333-357.

[127] R.H. Hurt, G.P. Crawford, H.-S. Shim, Proc. Combust. Inst. 28 (2000) 2539-2546.

[128] T. Ishiguro, Y. Takatori, K. Akihama, Combust. Flame 108 (1997) 231-234.

[129] L.B. Ebert, J.C. Scanlon, C.A. Clausen, Energy Fuels 2 (1988) 438-445.

[130] M.S. Dresselhaus, G. Dresselhaus, P.C. Eklund, Science of Fullerenes and Carbon Nanotubes. 1996, San Diego: Academic Press. 965.

[131] I. Colbeck, B. Atkinson, Y. Johar, J. Aerosol Sci. 28 (1997) 715-723.

[132] J. Lahaye, F. Ehrburger-Dolle, Carbon 32 (7) (1994) 1319-1324.

[133] T. Ishiguro, N. Suzuki, Y. Fujitani, H. Morimoto, Combust. Flame 85 (1991) 1-6.

[134] Á.B. Palotás, L.C. Rainey, A.F. Sarofim, J.B. Vander Sande, P. Ciambelli, Energy Fuels 10 (1) (1996) 254-259.

[135] H. Zhao, N. Ladommatos, Prog. Energy Combust. Sci. 24 (3) (1998) 221-255.

[136] C. Schulz, B.F. Kock, M. Hofmann, H.A. Michelsen, S. Will, B. Bougie, R. Suntz, G.J. Smallwood, Appl. Phys. B 83 (3) (2006) 333-354.

[137] A. D'Anna, Proc. Combust. Inst. 32 (2009) 593-613.

[138] C. Lou, C. Chen, Y.P. Sun, H.C. Zhou, Science China Technological Sciences 53 (8) (2010) 2129-2141.

[139] G.J. Nathan, P.A.M. Kalt, Z.T. Alwahabi, B.B. Dally, P.R. Medwell, Q.N. Chan, Prog. Energy Combust. Sci. 38 (2012) 41-61.

[140] P. Desgroux, X. Mercier, K.A. Thomson, Proc. Combust. Inst. 34 (2013) 1713-1738. 
[141] D.A. Lack, H. Moosmüller, G.R. McMeeking, R.K. Chakrabarty, D. Baumgardner, Analytical and Bioanalytical Chemistry 406 (1) (2014) 99-122.

[142] H.A. Michelsen, C. Schulz, G.J. Smallwood, S. Will, Prog. Energy Combust. Sci. 51 (2015) 2-48.

[143] M. Klassen, Y.R. Sivathanu, J.P. Gore, Combust. Flame 90 (1992) 34-44.

[144] M.Y. Choi, A. Hamins, G.W. Mulholland, T. Kashiwagi, Combust. Flame 99 (1994) 174-186.

[145] S. De luliis, M. Barbini, S. Benecchi, F. Cignoli, G. Zizak, Combust. Flame 115 (1998) 253-261.

[146] B.A. Fischer, J.B. Moss, Combust. Sci. Technol. 138 (1998) 43-61.

[147] F. Cignoli, S. De luliis, V. Manta, G. Zizak, Appl. Opt. 40 (30) (2001) 5370-535378.

[148] D.R. Snelling, K.A. Thomson, G.J. Smallwood, Ö.L. Gülder, E.J. Weckman, R.A. Fraser, AlAA Journal 40 (9) (2002) 1789-1795.

[149] J.J. Murphy, C.R. Shaddix, Combust. Flame 143 (2005) 1-10.

[150] K.A. Thomson, Ö.L. Gülder, E.J. Weckman, R.A. Fraser, G.J. Smallwood, D.R. Snelling, Combust. Flame 140 (2005) 222-232.

[151] F. Liu, K.A. Thomson, H. Guo, G.J. Smallwood, Combust. Flame 146 (2006) 456-471.

[152] S. De luliis, F. Migliorini, F. Cignoli, G. Zizak, Proc. Combust. Inst. 31 (2007) 869-876.

[153] I. Ayranci, R. Vaillon, N. Selçuk, J. Quant. Spectrosc. Radiat. Transfer 109 (2008) 349-361.

[154] P.B. Kuhn, B. Ma, B.C. Connelly, M.D. Smooke, M.B. Long, Proc. Combust. Inst. 33 (2011) 743-750.

[155] Q. Huang, F. Wang, J. Yan, Y. Chi, Appl. Opt. 51 (15) (2012) 2968-2978.

[156] H. Guo, J.A. Castillo, P.B. Sunderland, Appl. Opt. 52 (33) (2013) 8040-8047.

[157] F. Liu, K.A. Thomson, G.J. Smallwood, Combust. Flame 160 (2013) 1693-1705.

[158] G. Legros, Q. Wang, J. Bonnety, M. Kashif, C. Morin, J.-L. Consalvi, F. Liu, Combust. Flame 162 (2015) 27052719.

[159] M. Ni, H. Zhang, F. Wang, Z. Xie, Q. Huang, J. Yan, K. Cen, Applied Thermal Engineering 96 (2016) 421-431.

[160] A.E. Karatas, Ö.L. Gülder, Prog. Energy Combust. Sci. 38 (2012) 818-845.

[161] H.A. Michelsen, J. Chem. Phys. 118 (15) (2003) 7012-7045.

[162] R.J. Santoro, C.R. Shaddix, Laser-Induced Incandescence, in Applied Combustion Diagnostics, K. KohseHöinghaus and J.B. Jeffries, Editors. 2002, Taylor \& Francis: New York, NY. p. 252-286.

[163] P.C. Miles, R. Collin, L. Hildingsson, A. Hultqvist, Ö. Andersson, Proc. Combust. Inst. 31 (2007) 2963-2970.

[164] C.R. Shaddix, K.C. Smyth, Combust. Flame 99 (1994) 723-732.

[165] C.R. Shaddix, K.C. Smyth, Combust. Flame 107 (1996) 418-452.

[166] J. Appel, B. Jungfleisch, M. Marquardt, R. Suntz, H. Bockhorn, Proc. Combust. Inst. 26 (1996) 2387-2395.

[167] B. Mewes, J.M. Seitzman, Appl. Opt. 36 (1997) 709-717.

[168] P.S. Greenberg, J.C. Ku, Appl. Opt. 36 (22) (1997) 5514-5522.

[169] M.Y. Choi, K.A. Jensen, Combust. Flame 112 (1998) 485-491.

[170] R.L. Vander Wal, Twenty-Seventh Symp. (Internat.) Combust. 27 (1998) 59-67.

[171] L.A. Gritzo, Y.R. Sivathanu, W. Gill, Combust. Sci. Technol. 139 (1-6) (1998) 113-136.

[172] R.L. Vander Wal, T.M. Ticich, Appl. Opt. 38 (9) (1999) 1444-1451.

[173] D.J. Bryce, N. Ladommatos, H. Zhao, Appl. Opt. 39 (27) (2000) 5012-5022.

[174] B. Axelsson, R. Collin, P.-E. Bengtsson, Appl. Phys. B 72 (2001) 367-372.

[175] L.L. McCrain, W.L. Roberts, Combust. Flame 140 (2005) 60-69.

[176] M.D. Smooke, M.B. Long, B.C. Connelly, M.B. Colket, R.J. Hall, Combust. Flame 143 (2005) 613-628.

[177] J. Delhay, P. Desgroux, E. Therssen, H. Bladh, P.-E. Bengtsson, H. Hönen, J.D. Black, I. Vallet, Appl. Phys. B 95 (2009) 825-838.

[178] J. Zerbs, K.P. Geigle, O. Lammel, J. Hader, R. Stirn, R. Hadef, W. Meier, Appl. Phys. B 96 (2009) 683-694.

[179] S. De luliis, F. Cignoli, G. Zizak, Appl. Opt. 44 (34) (2005) 7414-7423.

[180] D.R. Snelling, G.J. Smallwood, F. Liu, Ö.L. Gülder, W.D. Bachalo, Appl. Opt. 44 (31) (2005) 6773-6785.

[181] F. Liu, D.R. Snelling, K.A. Thomson, G.J. Smallwood, Appl. Phys. B 96 (4) (2009) 623-636.

[182] B.M. Crosland, M.R. Johnson, K.A. Thomson, Appl. Phys. B 102 (2011) 173-183.

[183] C.F. Bohren, D.R. Huffman, Absorption and Scattering of Light by Small Particles. 1983, New York: John Wiley and Sons. 
[184] R. Stirn, T.G. Baquet, S. Kanjarkar, W. Meier, K.P. Geigle, H.H. Grotheer, C. Wahl, M. Aigner, Combust. Sci. Technol. 181 (2009) 329-349.

[185] A.V. Filippov, M.W. Markus, P. Roth, J. Aerosol Sci. 30 (1999) 71-87.

[186] R. Starke, B. Kock, P. Roth, Shock Waves 12 (2003) 351-360.

[187] H. Bladh, J. Johnsson, N.-E. Olofsson, A. Bohlin, P.-E. Bengtsson, Proc. Combust. Inst. 33 (2011) 641-648.

[188] H. Bladh, N.-E. Olofsson, T. Mouton, J. Simonsson, X. Mercier, A. Faccinetto, P.-E. Bengtsson, P. Desgroux, Proc. Combust. Inst. 35 (2015) 1843-1850.

[189] T. Mouton, X. Mercier, M. Wartel, N. Lamoureux, P. Desgroux, Appl. Phys. B 112 (2013) 369-379.

[190] H. Bladh, J. Johnsson, P.-E. Bengtsson, Appl. Phys. B 96 (4) (2009) 645-656.

[191] N.-E. Olofsson, J. Simonsson, S. Török, H. Bladh, P.-E. Bengtsson, Appl. Phys. B 119 (4) (2015) 669-683.

[192] P.-E. Bengtsson, M. Aldén, Appl. Phys. B 60 (1995) 51-59.

[193] T.C. Cole, W.A. Cole, T.M. Brown, R.W. Pitz, Meas. Sci. Technol. 13 (2002) 464-470.

[194] G.S. Humphries, J. Dunn, M.M. Hossain, M. Lengden, I.S. Burns, J.D. Black, Appl. Phys. B 119 (2015) 709715.

[195] C.S. McEnally, Ü.Ö. Köylü, L.D. Pfefferle, D.E. Rosner, Combust. Flame 109 (1997) 701-720.

[196] Ü.Ö. Köylü, C.S. McEnally, D.E. Rosner, L.D. Pfefferle, Combust. Flame 110 (1997) 494-507.

[197] A.D. Eisner, D.E. Rosner, Combust. Flame 61 (1985) 153-166.

[198] W.H. Dalzell, G.C. Williams, H.C. Hottel, Combust. Flame 14 (1970) 161-170.

[199] W.L. Flower, Phys. Rev. Lett. 51 (25) (1983) 2287-2290.

[200] R. Di Sante, Optics and Lasers in Engineering 51 (2013) 783-789.

[201] B. Yang, B. Hu, Ü.Ö. Köylü, Combust. Sci. Technol. 177 (2005) 1603-1626.

[202] Y. Xu, C.F. Lee, Appl. Opt. 45 (9) (2006) 2046-2057.

[203] B. Tian, Y. Gao, S. Balusamy, S. Hochgreb, Appl. Phys. B 120 (2015) 469-487.

[204] M. Kashif, J. Bonnety, P. Guibert, C. Morin, G. Legros, Opt. Express 20 (27) (2012) 28742-28751.

[205] S. De Iuliis, F. Cignoli, S. Benecchi, G. Zizak, Appl. Opt. 37 (33) (1998) 7865-7874.

[206] R.J. Santoro, J.H. Miller, Langmuir 3 (1987) 244-254.

[207] B. Yang, Ü.Ö. Köylü, Combust. Flame 141 (2005) 55-65.

[208] S. De Iuliis, F. Cignoli, S. Benecchi, G. Zizak, Twenty-Seventh Symp. (Internat.) Combust. 27 (1549-1555) (1998) 1549.

[209] N. Lu, C.M. Sorensen, Phys. Rev. E 50 (4) (1994) 3109-3115.

[210] S. di Stasio, Appl. Phys. B 70 (2000) 635-643.

[211] G. Shu, T.T. Charalampopoulos, Appl. Opt. 39 (36) (2000) 6713-6724.

[212] H. Oltmann, J. Reimann, S. Will, Combust. Flame 157 (2010) 516-522.

[213] O. Link, D.R. Snelling, K.A. Thomson, G.J. Smallwood, Proc. Combust. Inst. 33 (2011) 847-854.

[214] H. Oltmann, J. Reimann, S. Will, Appl. Phys. B 106 (2012) 171-183.

[215] K. Skorupski, J. Mroczka, N. Riefler, H. Oltmann, S. Will, T. Wriedt, J. Quant. Spectrosc. Radiat. Transfer 119 (2013) 53-66.

[216] C. Caumont-Prim, J. Yon, A. Coppalle, F.X. Ouf, K.F. Ren, J. Quant. Spectrosc. Radiat. Transfer 126 (2013) 140-149.

[217] N.J. Kempema, M.B. Long, Combust. Flame 164 (2016) 373-385.

[218] C.M. Sorensen, J. Cai, N. Lu, Appl. Opt. 31 (30) (1992) 6547-6555.

[219] S. di Stasio, P. Massoli, M. Lazzaro, J. Aerosol Sci. 27 (6) (1996) 897-913.

[220] B. Yang, Ü.Ö. Köylü, J. Quant. Spectrosc. Radiat. Transfer 93 (2005) 289-299.

[221] J. Reimann, S.A. Kuhlmann, S. Will, Appl. Phys. B 96 (4) (2009) 583-592.

[222] D.R. Snelling, O. Link, K.A. Thomson, G.J. Smallwood, Appl. Phys. B 104 (2011) 385-397.

[223] B.M. Crosland, K.A. Thomson, M.R. Johnson, Appl. Phys. B 112 (2013) 381-393.

[224] T.L. Farias, M.G. Carvalho, Ü.Ö. Köylü, G.M. Faeth, J. Heat Transfer 117 (1995) 152-159.

[225] T.L. Farias, Ü.Ö. Köylü, M.G. Carvalho, Appl. Opt. 35 (33) (1996) 6560-6567.

[226] J. Yon, F. Liu, A. Bescond, C. Caumont-Prim, C. Rozé, F.-X. Ouf, A. Coppalle, J. Quant. Spectrosc. Radiat. Transfer 133 (2014) 374-381. 
[227] M.I. Mishchenko, L. Liu, D.W. Mackowski, J. Quant. Spectrosc. Radiat. Transfer 123 (2013) 135-144.

[228] W.A. England, Combust. Sci. Technol. 46 (1-2) (1986) 83-93.

[229] J.P. Hessler, S. Seifert, R.E. Winans, Proc. Combust. Inst. 29 (2) (2002) 2743-2748.

[230] C. Gardner, G.N. Greaves, G.K. Hargrave, S. Jarvis, P. Wildman, F. Meneau, W. Bras, G. Thomas, Nuclear Instruments \& Methods in Physics Research B 238 (2005) 334-339.

[231] H.K. Kammler, G. Beaucage, D.J. Kohls, N. Agashe, J. Ilavsky, J. Appl. Phys. 97 (5) (2005) 054309.

[232] S. di Stasio, J.B.A. Mitchell, J.L. LeGarrec, L. Biennier, M. Wulff, Carbon 44 (2006) 1267-1279.

[233] J.B.A. Mitchell, J.L. Le Garrec, A.I. Florescu-Mitchell, S. di Stasio, Combust. Flame 145 (2006) 80-87.

[234] M. Sztucki, T. Narayanan, G. Beaucage, J. Appl. Phys. 101 (2007) 114304.

[235] F. Ossler, S.E. Canton, J. Larsson, Carbon 47 (2009) 3498-3507.

[236] J.B.A. Mitchell, S. di Stasio, J.L. LeGarrec, A.I. Florescu-Mitchell, T. Narayanan, M. Sztucki, J. Appl. Phys. 105 (2009) 124904.

[237] J.B.A. Mitchell, J.L. LeGarrec, G. Saidani, F. Lefuevre, S. di Stasio, Energy Fuels 27 (2013) 4891-4898.

[238] F. Ossler, L. Vallenhag, S.E. Canton, J.B.A. Mitchell, J.L. Le Garrec, M. Sztucki, S. di Stasio, Carbon 51 (2013) 1-19.

[239] A. Braun, N. Shah, F.E. Huggins, K.E. Kelley, A.F. Sarofim, C. Jacobsen, S. Wirick, H. Francis, J. Ilavsky, G.E. Thomas, G.P. Huffman, Carbon 43 (2005) 2588-2599.

[240] J.B.A. Mitchell, C. Rebrion-Rowe, J.L. LeGarrec, G. Taupier, N. Huby, M. Wulff, Astron. Astrophys. 386 (2002) 743-747.

[241] H. Wang, B. Zhao, B. Wyslouzil, K. Streletzky, Proc. Combust. Inst. 29 (2002) 2749-2757.

[242] H.A. Michelsen, F. Liu, B.F. Kock, H. Bladh, A. Boiarciuc, M. Charwath, T. Dreier, R. Hadef, M. Hofmann, J. Reimann, S. Will, P.-E. Bengtsson, H. Bockhorn, F. Foucher, K.P. Geigle, C. Mounaïm-Rousselle, C. Schulz, R. Stirn, B. Tribalet, R. Suntz, Appl. Phys. B 87 (2007) 503-521.

[243] H. Bladh, J. Johnsson, J. Rissler, H. Abdulhamid, N.-E. Olofsson, M. Sanati, J. Pagels, P.-E. Bengtsson, Appl. Phys. B 104 (2011) 331-341.

[244] R.P. Bambha, H.A. Michelsen, J. Aerosol Sci. 88 (2015) 159-181.

[245] S.-A. Kuhlmann, J. Reimann, S. Will, J. Aerosol Sci. 37 (2006) 1696-1716.

[246] F. Liu, G.J. Smallwood, Appl. Phys. B 104 (2011) 343-355.

[247] F. Liu, G.J. Smallwood, D.R. Snelling, J. Quant. Spectrosc. Radiat. Transfer 93 (2005) 301-312.

[248] A.V. Filippov, M. Zurita, D.E. Rosner, J. Colloid Interface Sci. 229 (2000) 261-273.

[249] J. Johnsson, H. Bladh, N.-E. Olofsson, P.-E. Bengtsson, Appl. Phys. B 112 (3) (2013) 321-332.

[250] F. Liu, M. Yang, F.A. Hill, D.R. Snelling, G.J. Smallwood, Appl. Phys. B 83 (3) (2006) 383-395.

[251] H. Bladh, J. Johnsson, P.-E. Bengtsson, Appl. Phys. B 90 (2008) 109-125.

[252] E. Cenker, G. Bruneaux, T. Dreier, C. Schulz, Appl. Phys. B 118 (2015) 169-183.

[253] R.P. Bambha, M.A. Dansson, P.E. Schrader, H.A. Michelsen, Appl. Phys. B 112 (3) (2013) 343-358.

[254] S. Bannerjee, B. Menkiel, L.C. Ganippa, Appl. Phys. B 96 (2009) 571-579.

[255] J. Johnsson, H. Bladh, P.-E. Bengtsson, Appl. Phys. B 99 (2010) 817-823.

[256] F. Liu, B.J. Stagg, D.R. Snelling, G.J. Smallwood, Int. J. Heat Mass Transfer 49 (2006) 777-788.

[257] F. Liu, G.J. Smallwood, Applied Physics B: Lasers and Optics 112 (2013) 307-319.

[258] F. Goulay, L. Nemes, P.E. Schrader, H.A. Michelsen, Mol. Phys. 108 (7-9) (2010) 1013-1025.

[259] F. Goulay, P.E. Schrader, L. Nemes, M.A. Dansson, H.A. Michelsen, Proc. Combust. Inst. 32 (2009) 963-970.

[260] R. Niessner, W. Robers, A. Krupp, Fresenius. J. Anal. Chem. 341 (1991) 207-213.

[261] J.H. Miller, J.D. Herdman, C.D.O. Green, E.M. Webster, Proc. Combust. Inst. 34 (2013) 3669-3675.

[262] R.C. Millikan, Journal of the Optical Society of America 51 (6) (1961) 698-699.

[263] E.M. Adkins, J.A. Giaccai, J.H. Miller, Proc. Combust. Inst. This issue (2017) in press.

[264] S. Chippet, W.A. Gray, Combust. Flame 31 (1978) 149-159.

[265] S.C. Lee, C.L. Tien, Proc. Combust. Inst. 18 (1981) 1159-1166.

[266] J. Mullins, A. Williams, Fuel 66 (1987) 277-280.

[267] T.C. Williams, C.R. Shaddix, K.A. Jensen, J.M. Suo-Anttila, Int. J. Heat Mass Transfer 50 (2007) 1616-1630.

[268] F. Migliorini, S. De luliis, S. Maffi, G. Zizak, Appl. Phys. B 120 (2015) 417-427. 
[269] G. Cléon, T. Amodeo, A. Faccinetto, P. Desgroux, Appl. Phys. B 104 (2) (2011) 297-305.

[270] C.J. Damm, D. Lucas, R.F. Sawyer, C.P. Koshland, Proc. Combust. Inst. 29 (2002) 2767-2774.

[271] C.B. Stipe, B.S. Higgins, D. Lucas, C.P. Koshland, R.F. Sawyer, Proc. Combust. Inst. 29 (2002) 2759-2766.

[272] C.E. Batten, Appl. Opt. 24 (8) (1985) 1193-1199.

[273] J.-S. Wu, S.S. Krishnan, G.M. Faeth, J. Heat Transfer 119 (2) (1997) 230-237.

[274] B.M. Vaglieco, F. Beretta, A. D'Alessio, Combust. Flame 79 (1990) 259-271.

[275] Ü.Ö. Köylü, G.M. Faeth, J. Heat Transfer 116 (1994) 152-159.

[276] Ü.Ö. Köylü, G.M. Faeth, J. Heat Transfer 118 (1996) 415-421.

[277] S.S. Krishnan, K.-C. Lin, G.M. Faeth, J. Heat Transfer 123 (2001) 331-339.

[278] F. Ossler, J. Larsson, Chem. Phys. Lett. 387 (2004) 367-371.

[279] F. Ossler, J. Larsson, J. Appl. Phys. 98 (2005) 114317.

[280] F. Ossler, S.E. Canton, L.R. Wellenberg, A. Engdahl, S. Seifert, J.P. Hessler, R.S. Tranter, Carbon 96 (2016) 782-798.

[281] J.H. Frank, A. Shavorskiy, H. Bluhm, B. Coriton, E. Huang, D.L. Osborn, Appl. Phys. B 117 (2014) 493-499.

[282] J.B.A. Mitchell, C. Rebrion-Rowe, J.-L. Legarrec, G. Taupier, N. Huby, M. Wulff, Combust. Flame 131 (2002) 308-315.

[283] J.B.A. Mitchell, J.L. LeGarrec, D. Travers, B.R. Rowe, R.J. Randler, A. Plech, M. Wulff, Nuclear Instruments \& Methods in Physics Research B 207 (2003) 227-231.

[284] A. Bohlin, C.J. Kliewer, J. Phys. Chem. Lett. 6 (2015) 643-649.

[285] F. Cignoli, S. Benecchi, G. Zizak, Opt. Lett. 17 (4) (1992) 229-231.

[286] M.G. Allen, K.R. McManus, D.M. Sonnenfroh, P.H. Paul, Appl. Opt. 34 (27) (1995) 6287-6300.

[287] K. Hayashida, K. Amagai, K. Satoh, M. Arai, J. Eng. Gas Turbines Power 128 (2006) 241-246.

[288] C. Moreau, E. Therssen, P. Desgroux, J.F. Pauwels, A. Chapput, M. Barj, Appl. Phys. B 76 (5) (2003) 597602.

[289] J.E. Harrington, K.C. Smyth, Chem. Phys. Lett. 202 (3,4) (1993) 196-202.

[290] S. Böckle, J. Kazenwadel, T. Kunzelmann, D.-I. Shin, C. Schulz Appl. Phys. B 70 (2000) 733-735.

[291] C.S. McEnally, L.D. Pfefferle, Combust. Flame 121 (2000) 575-592.

[292] D.S. Coe, J.I. Steinfeld, Chem. Phys. Lett. 76 (3) (1980) 485-489.

[293] D.S. Coe, B.S. Haynes, J.I. Steinfeld, Combust. Flame 43 (1981) 211-214.

[294] A. Di Lorenzo, A. D'Alessio, V. Cincotti, S. Masi, P. Menna, C. Venitozzi, Proc. Combust. Inst. 18 (1981) 485491.

[295] J.H. Miller, W.G. Mallard, K.C. Smyth, Combust. Flame 47 (1982) 205-214.

[296] F. Beretta, V. Cincotti, A. D'Alessio, P. Menna, Combust. Flame 61 (1985) 211-218.

[297] P. Andreussi, B. Barbieri, L. Petarca, Combust. Sci. Technol. 49 (1986) 123-141.

[298] A. Gomez, M.G. Littman, I. Glassman, Combust. Flame 70 (1987) 225-241.

[299] L. Petarca, F. Marconi, Combust. Flame 78 (1989) 308-325.

[300] F. Beretta, A. D'Alessio, A. D'Orsi, P. Minutolo, Combust. Sci. Technol. 85 (1992) 455-470.

[301] A. Thöny, M.J. Rossi, J. Photochem. Photobiol., A 104 (1997) 25-33.

[302] R.L. Vander Wal, Combust. Flame 112 (1998) 607-616.

[303] A. Ciajolo, R. Ragucci, B. Apicella, R. Barbella, M. de Joannon, A. Tregrossi, Chemosphere 42 (2001) 835841.

[304] A. Ciajolo, A. Tregrossi, R. Barbella, R. Ragucci, B. Apicella, M. de Joannon, Combust. Flame 125 (2001) 1225-1229.

[305] R.K. Hanson, Proc. Combust. Inst. 33 (2011) 1-40.

[306] F.N. Egolfopoulos, N. Hansen, Y. Ju, K. Kohse-Höinghaus, C.K. Law, F. Qi, Prog. Energy Combust. Sci. 43 (2014) 36-67.

[307] J. Kiefer, P. Ewart, Prog. Energy Combust. Sci. 37 (2011) 525-564.

[308] M. Aldén, J. Bood, Z. Li, M. Richter, Proc. Combust. Inst. 33 (2011) 69-97.

[309] J. Ballester, T. García-Armingol, Prog. Energy Combust. Sci. 36 (2010) 375-411. 


\section{Figure captions}

Figure 1. Schematic representation of soot formation and evolution in a flame. The molecular species and particles are not drawn to scale.

Figure 2. Contour plots of soot volume fraction. Volume fraction is shown in parts per million (ppm) for values inferred from (a) spectral soot emission (SSE) and (b) extinction techniques. Measurements were made in an ethylene-air co-flow diffusion flame as a function of radial distance from the centerline $(r)$ and height above the burner $(z)$. This figure is reproduced from Guo et al. [156].

Figure 3. Averaged images of LII from soot, laser-induced fluorescence (LIF) from partially oxidized fuel, and particle-image velocimetry (PIV) for flow fields in a direct-injection Diesel-engine cylinder. Measurements were timed with the engine cycle and were recorded at the crank angles listed in each panel. Measurements of LII, LIF, and PIV were performed separately. LII and LIF measurements were each averaged over 50 engine cycles, and PIV measurements were averaged over 100 skip-fired engine cycles. Top row: LII was measured using a 1064-nm laser sheet with a fluence of $0.6 \mathrm{~J} / \mathrm{cm}^{2}$. Signal was recorded at wavelengths shorter than $450 \mathrm{~nm}$. Middle row: LIF was measured using an excitation wavelength of $355 \mathrm{~nm}$ and detection at wavelengths longer than $400 \mathrm{~nm}$. Bottom row: PIV was measured with two 532-nm pulses separated by $10 \mu \mathrm{s}$. This figure is reproduced from Miles et al. [163].

Figure 4. Particle volume distribution functions inferred from SAXS measurements at selected HABs in an ethylene co-flow diffusion flame. $D(R)$ is the volume of a particle with a radius of $R$, times the number concentration of that particle size in the scattering volume. This figure is reproduced from Mitchell et al. [236]. 
Figure 5. Particle volume distribution functions inferred from SANS measurements at selected HABs in an ethylene co-flow diffusion flame. $P(R)$ is the volume of a particle with a radius of $R$, times the number concentration of that particle size in the scattering volume. The flame is the same as that used for the SAXS measurements shown in Fig. 4. This figure is reproduced from Mitchell et al. [233].

Figure 6. Illustration of the processes responsible for the evolution of the LII signal. Particles are heated by a laser absorption, oxidation, and annealing. Particles are cooled by conduction to the surrounding atmosphere, sublimation, thermionic emission, and radiative emission. Particles lose mass by sublimation and oxidation. This figure is reproduced from Michelsen et al. [142].

Figure 7. Primary-particle sizing in an ethylene-air premixed flat flame. (a) Normalized LII temporal profiles are shown for selected HABs. (b) Primary-particle sizes are shown as a function of HAB for

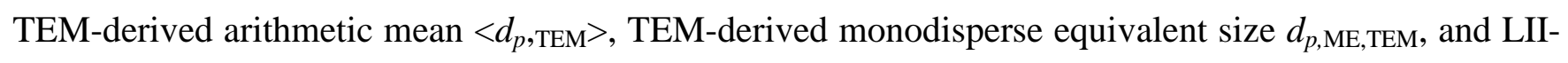
derived size $d_{p, \text { ME,LII }}$, assuming individual primary particles, $N_{p}=1$, and an aggregate of 100 primary particles, $N_{p}=100$. This figure is reproduced from Bladh et al. [187].

Figure 8. UV-visible spectra recorded in an ethylene-air premixed flame. Spectra were recorded at selected HABs (listed in legend) and equivalence ratios to yield the carbon-to-oxygen $\mathrm{C} / \mathrm{O}$ ratios given in the legend. $\mathrm{C} / \mathrm{O}$ ratio of 0.77 produces a slightly sooting flame, and $\mathrm{C} / \mathrm{O}$ ratio of 1.0 produces a fully sooting flame. This figure is reproduced from Basile et al. [70].

Figure 9. Visible spectra recorded at selected HABs in an ethylene-air premixed flame. The refractiveindex function for absorption $E(m)$ is proportional to the absorption cross section. The spectra have been 
normalized to one another in the range between 700 and $800 \mathrm{~nm}$. The scattering correction was estimated to be negligible. This figure is reproduced from Migliorini et al. [98].

Figure 10. Peak LII as a function of laser fluence. Peak LII fluence curves are shown for laser wavelengths of 532 and $1064 \mathrm{~nm}$ and for two positions in an ethylene/air co-flow diffusion flame. The center of the flame (open circles) has less mature soot than the edge of the flame (closed circles). This figure is adapted from López-Yglesias et al. [99].

Figure 11. Gas-phase NEXAFS spectra in a low-pressure jet flame. (a) Spectra of pure $\mathrm{CO}, \mathrm{CH}_{4}$, and $\mathrm{CO}_{2}$ were measured at $294 \mathrm{~K}$. (b) This absorption spectrum was measured in a 20-Torr methane jet flame with a co-flow of pure $\mathrm{O}_{2}$ and fit using a linear combination of reference absorption spectra from cold gas. This figure is reproduced from Frank et al. [281].

Figure 12. Simultaneous coherent Raman temperature imaging and wideband chemical detection in a fuel-rich premixed ethylene-air flat flame. (left panel) Temperature profile plotted as temperature on the $x$-axis and HAB on the $y$-axis (right panel) High-resolution pure-rotational Raman spectrum of the $\mathrm{N}_{2} \mathrm{~S}$ branch. The Raman shift is plotted on the $x$-axis, and the $y$-axis is the same as for the left panel. Reprinted with permission from Bohlin and Kliewer [284]. Copyright 2015 American Chemical Society. 


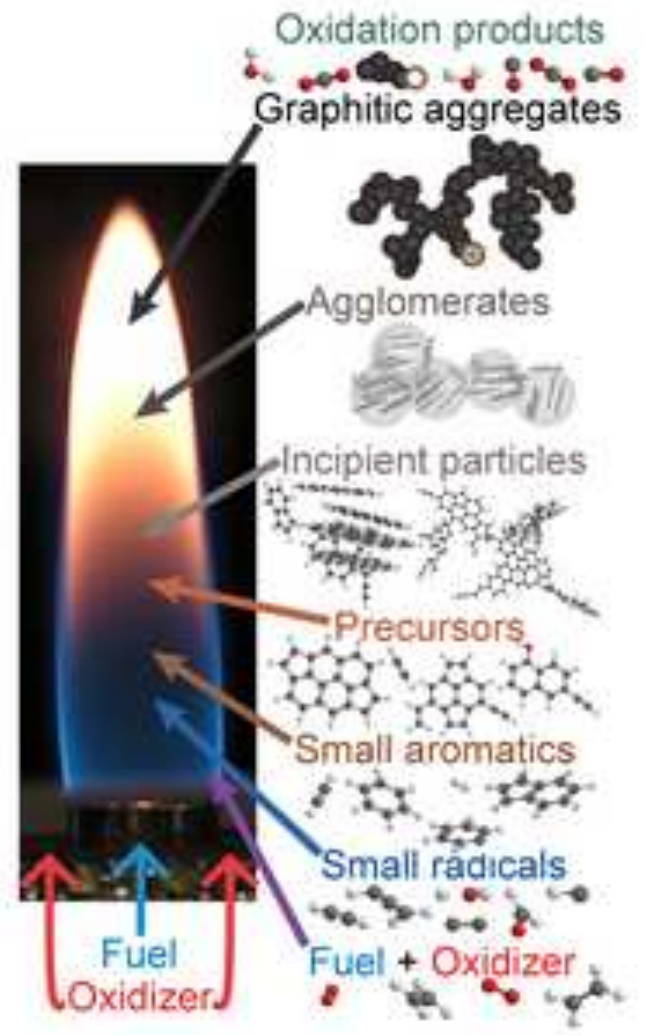




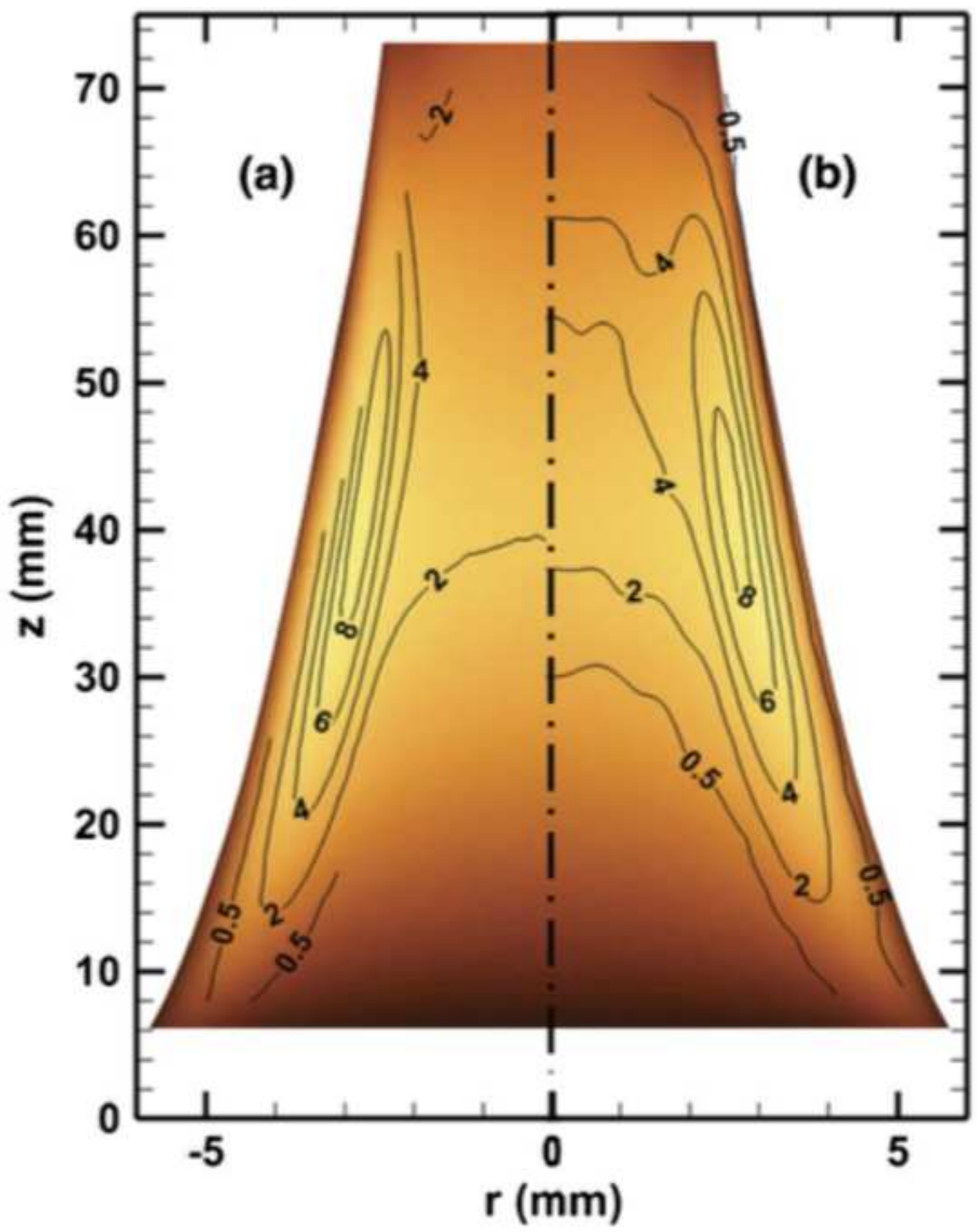




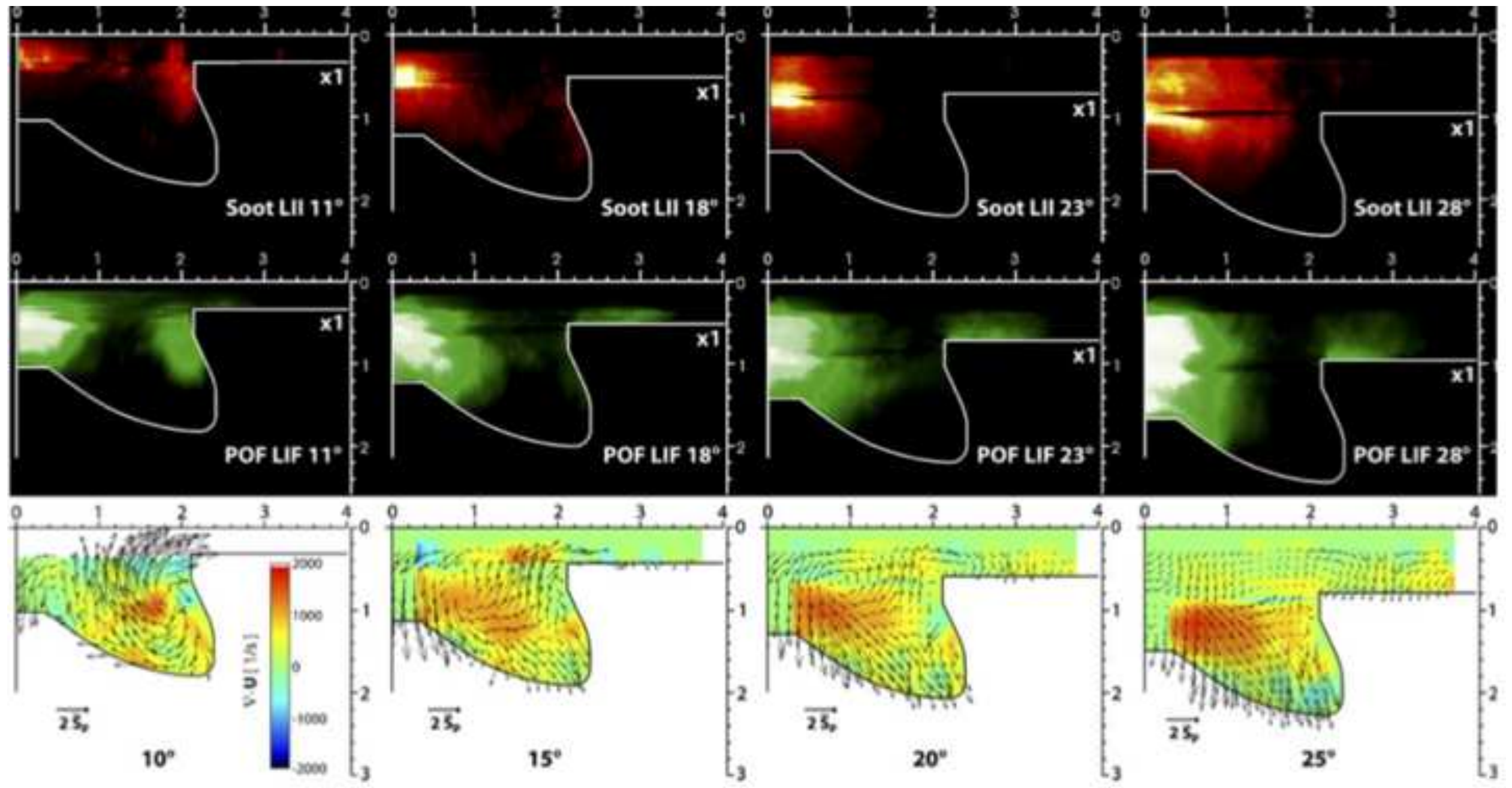



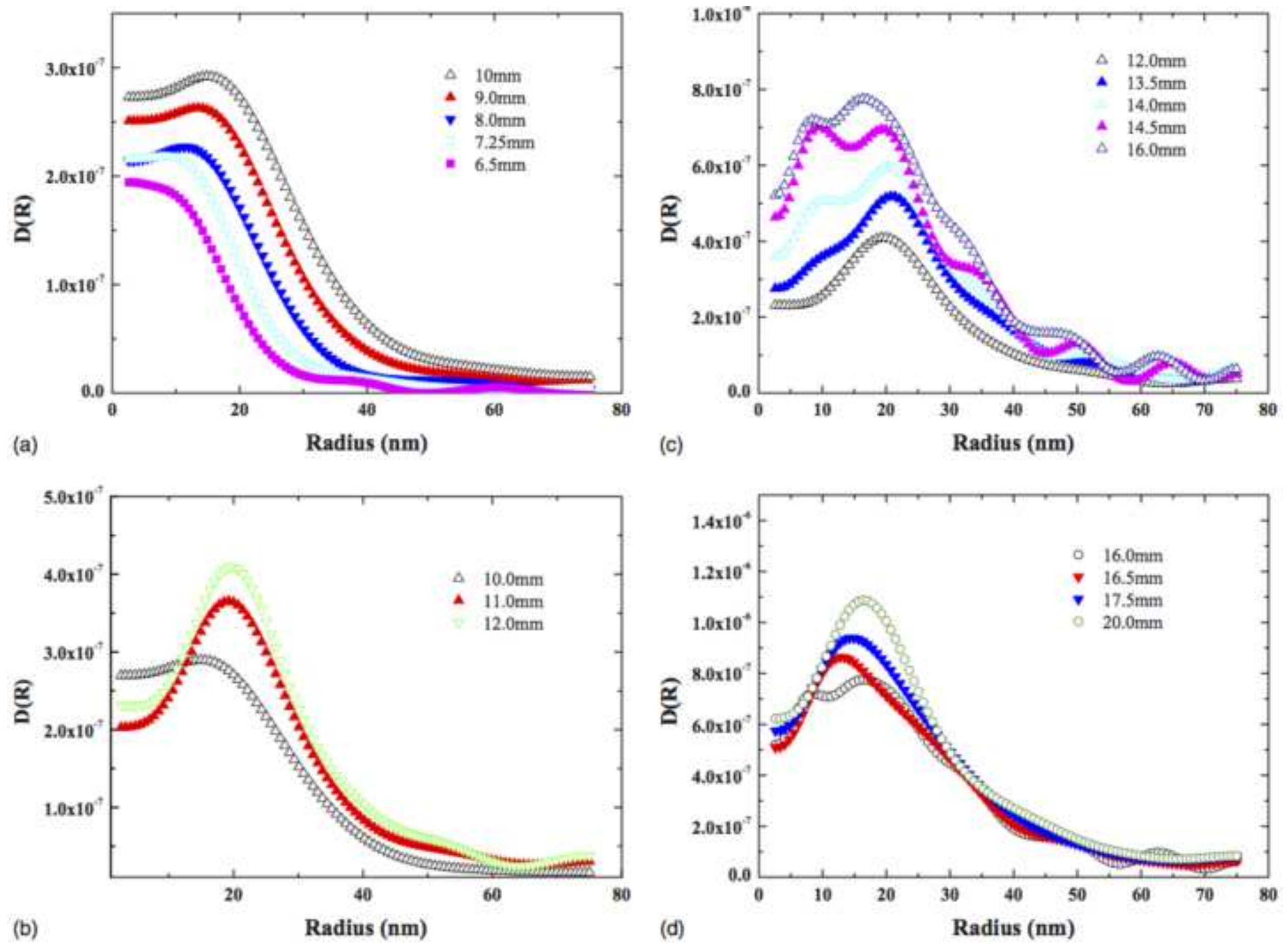


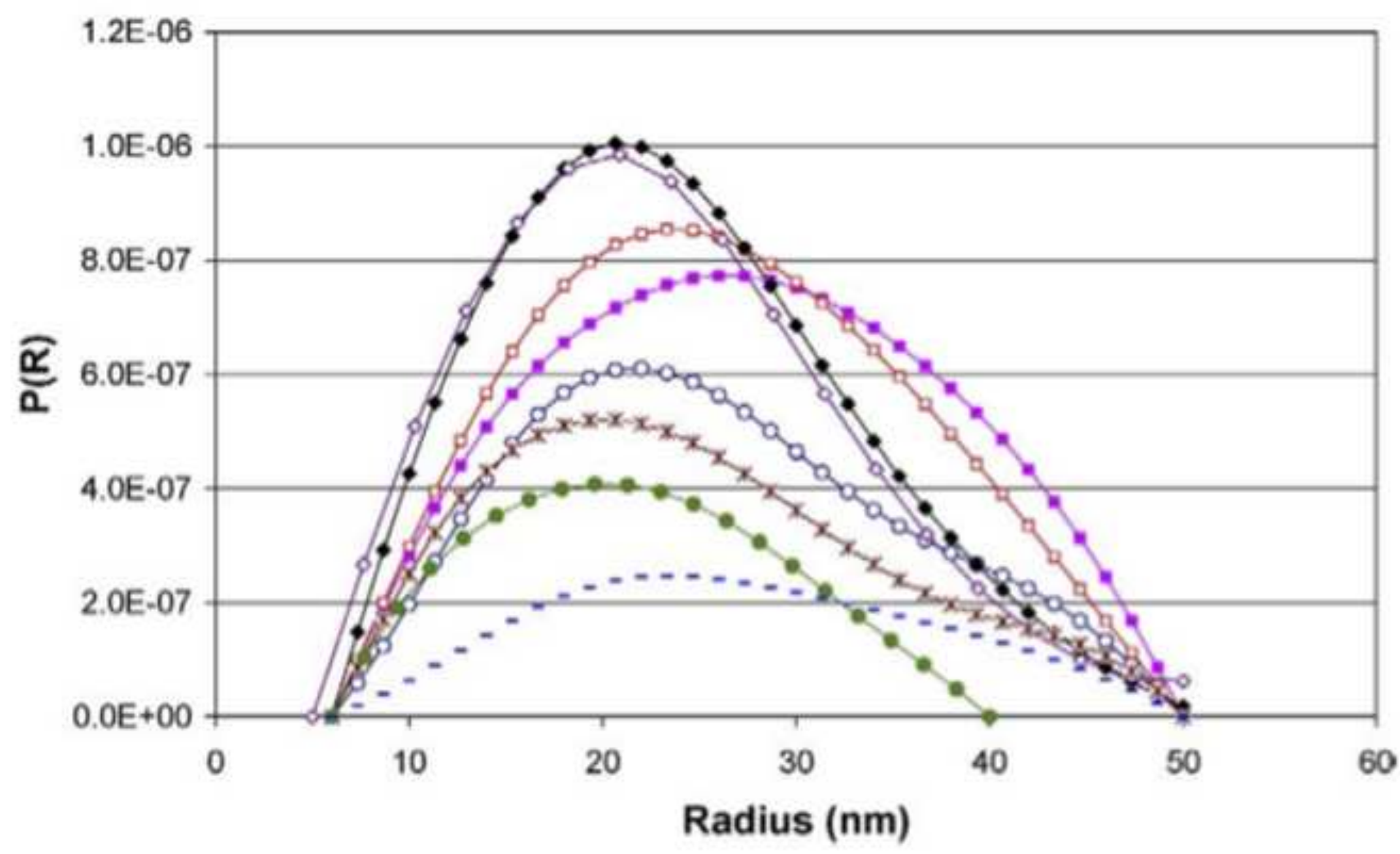




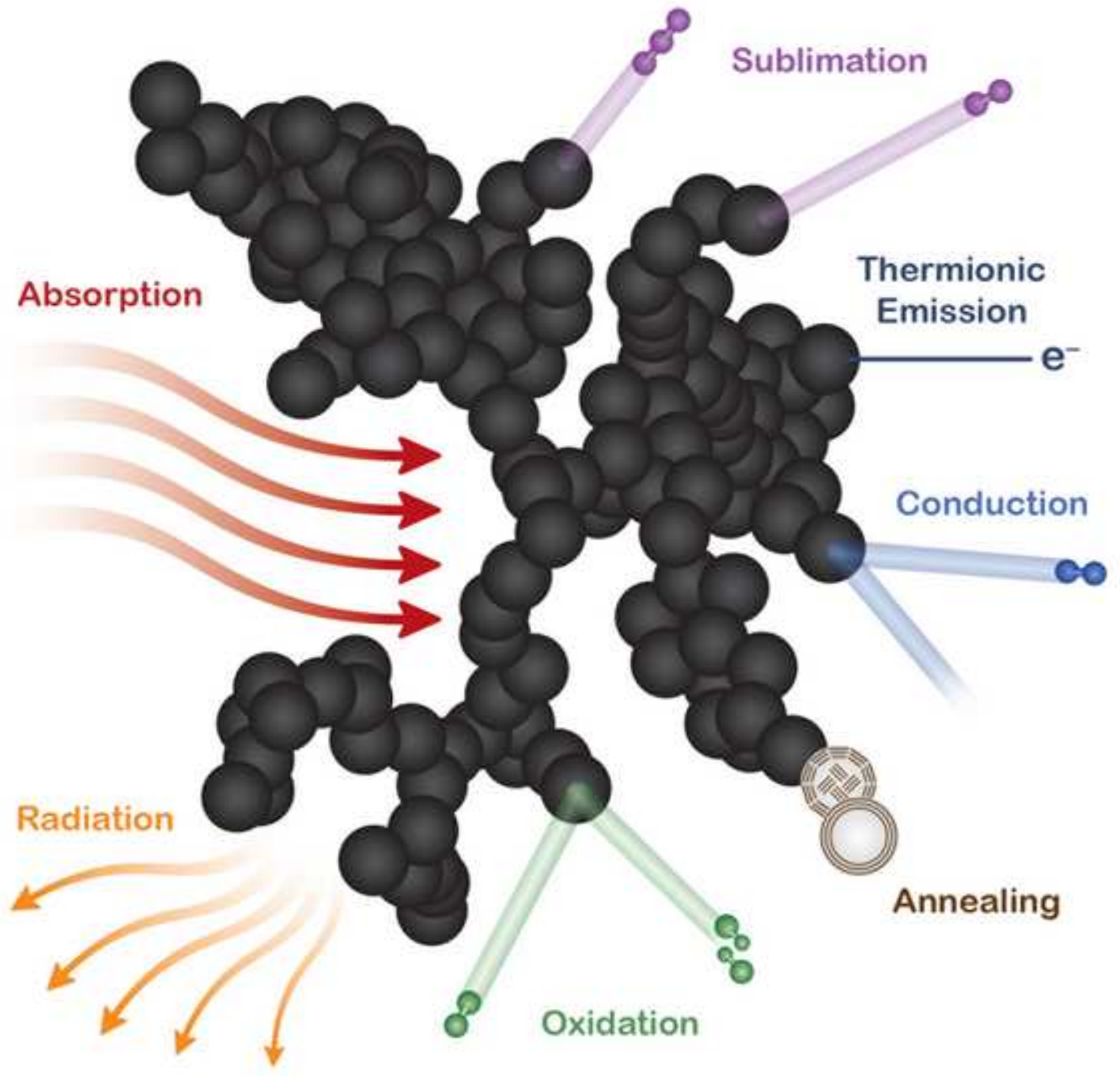



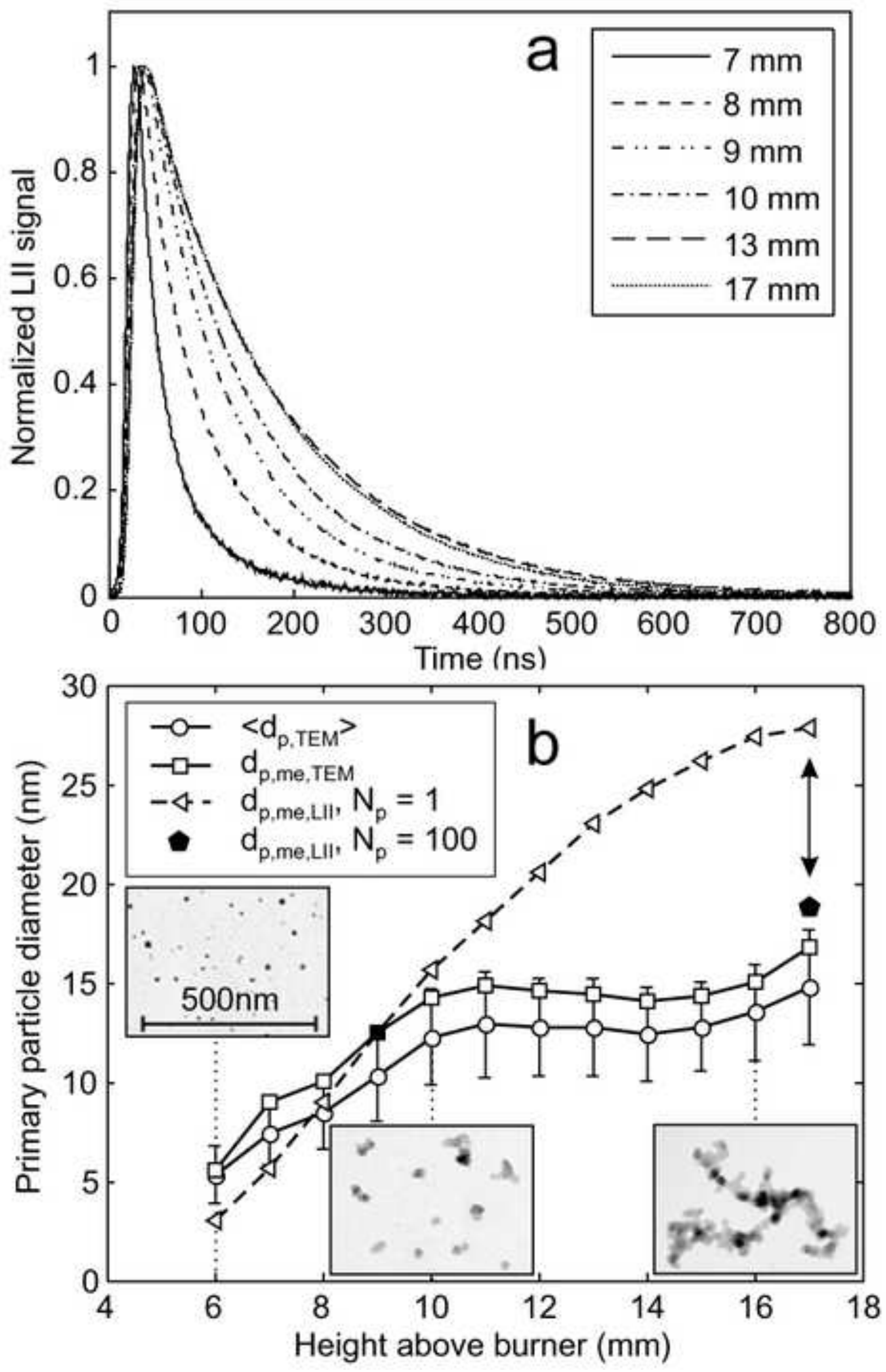


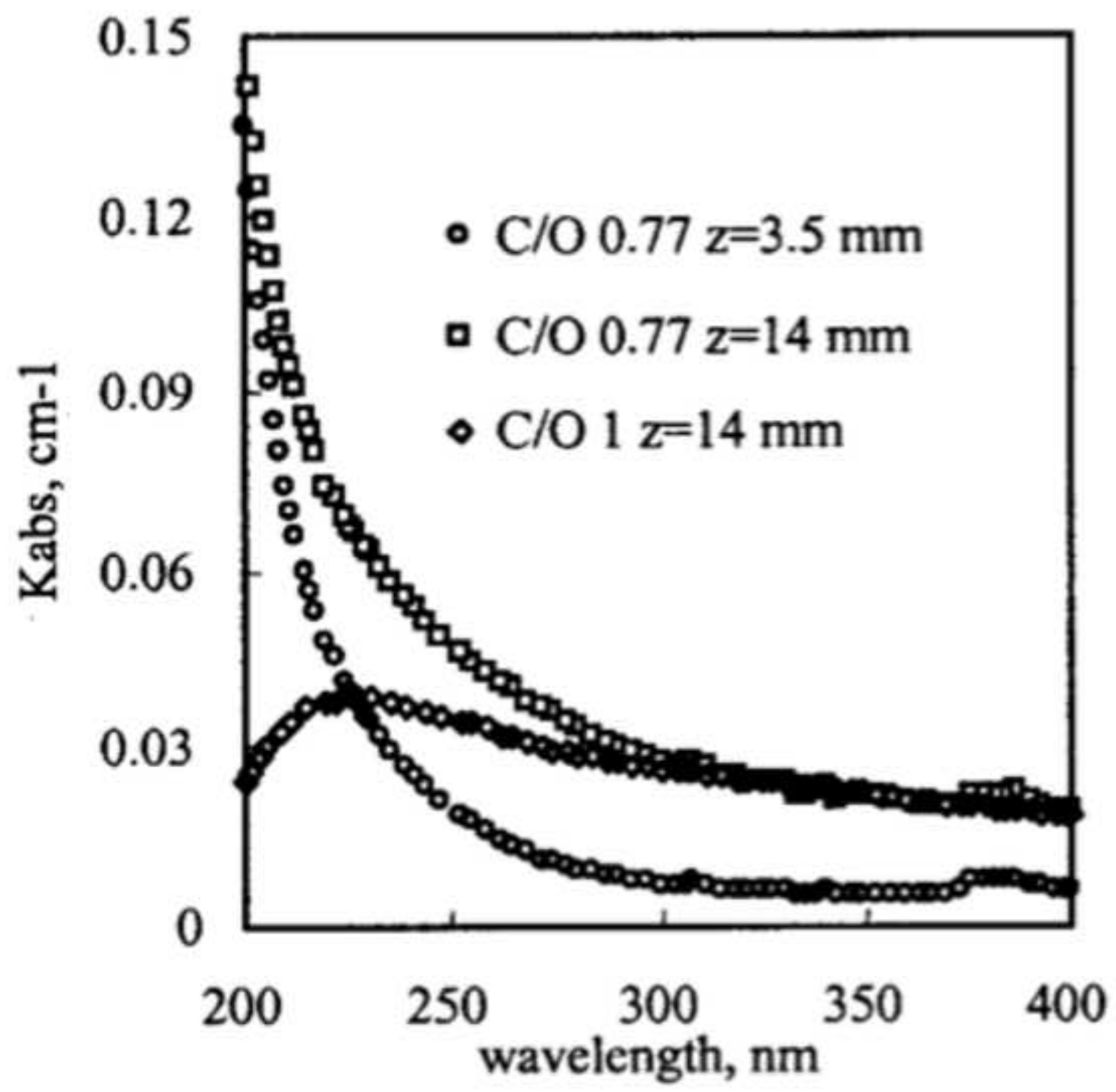




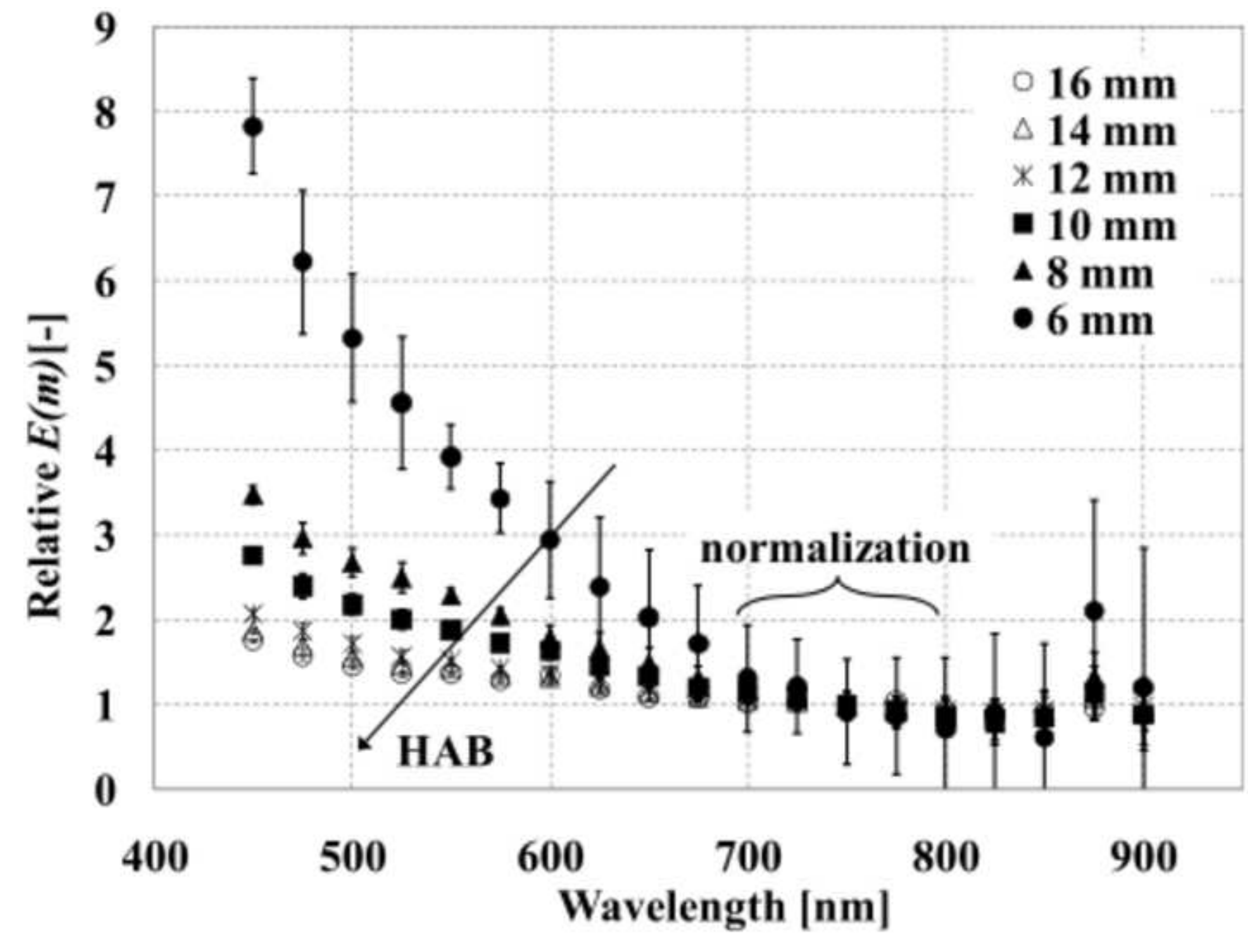




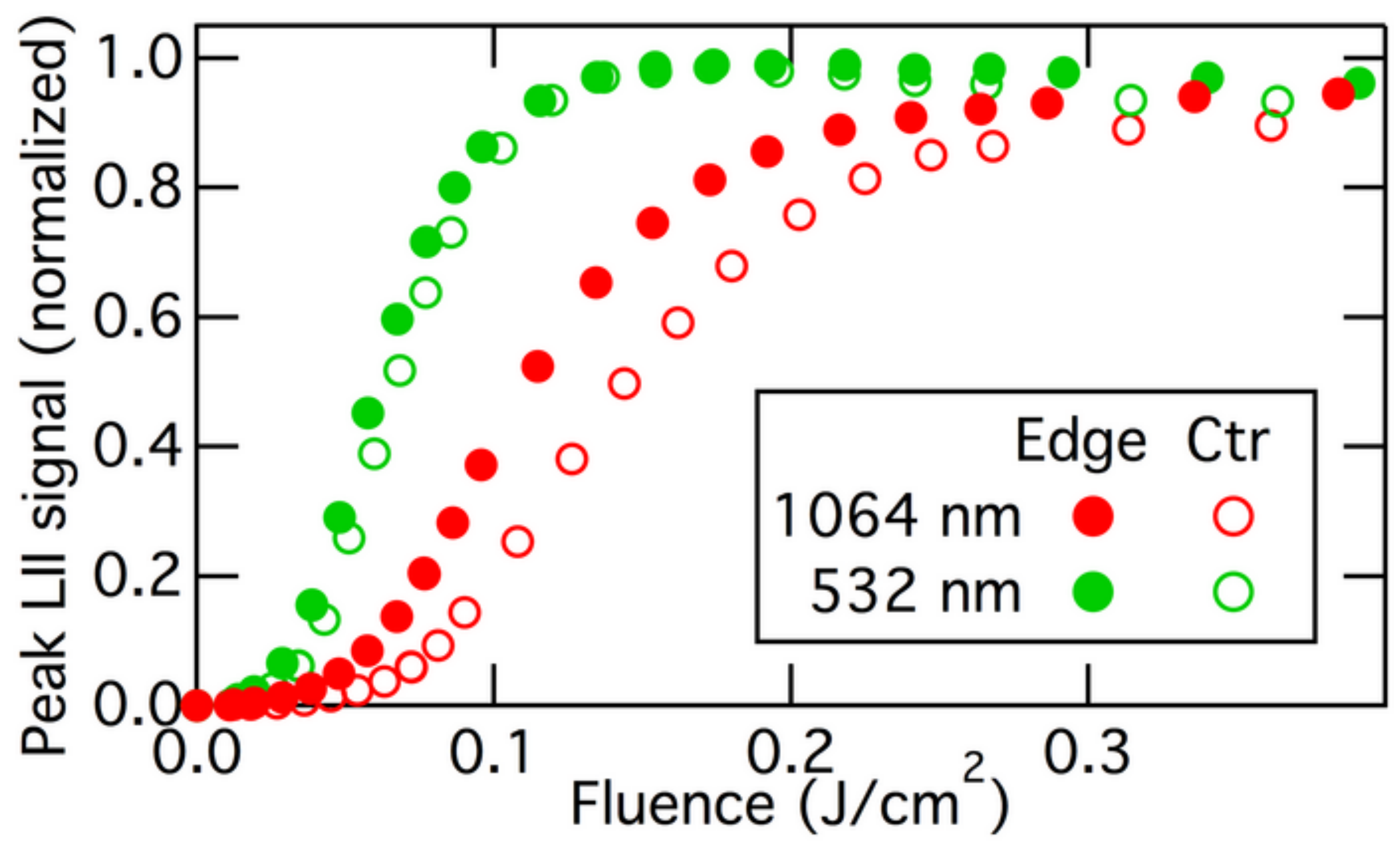



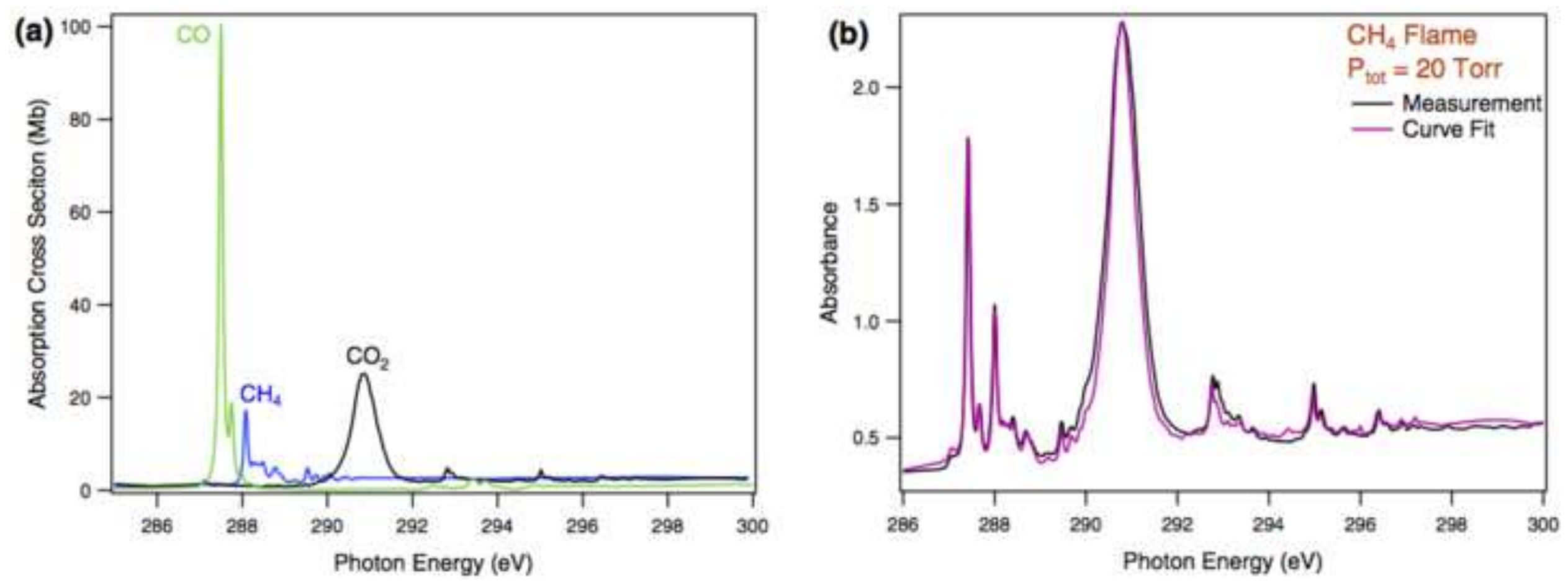


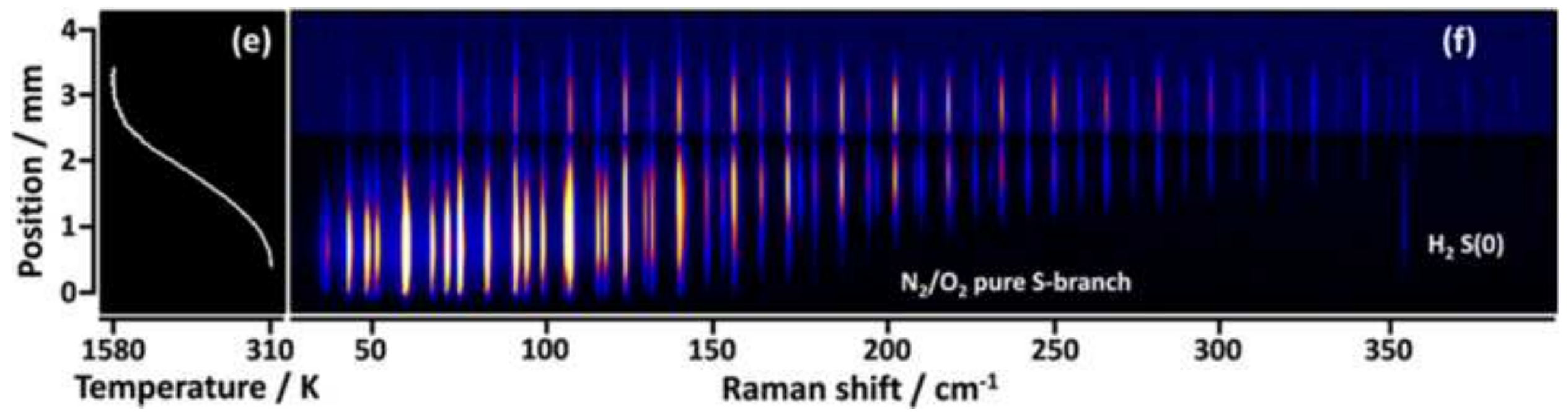

